\title{
A Local, Periactive Zone Endocytic Machinery at Photoreceptor Synapses in Close Vicinity to Synaptic Ribbons
}

\author{
Silke Wahl, Rashmi Katiyar, and Frank Schmitz \\ Saarland University, Institute of Anatomy and Cell Biology, Department Neuroanatomy, 66421 Homburg, Saar, Germany
}

Photoreceptor ribbon synapses are continuously active synapses with large active zones that contain synaptic ribbons. Synaptic ribbons are anchored to the active zones and are associated with large numbers of synaptic vesicles. The base of the ribbon that is located close to L-type voltage-gated $\mathrm{Ca}^{2+}$ channels is a hotspot of exocytosis. The continuous exocytosis at the ribbon synapse needs to be balanced by compensatory endocytosis. Recent analyses indicated that vesicle recycling at the synaptic ribbon is also an important determinant of synaptic signaling at the photoreceptor synapse. To get insights into mechanisms of vesicle recycling at the photoreceptor ribbon synapse, we performed super-resolution structured illumination microscopy and immunogold electron microscopy to localize major components of the endocytotic membrane retrieval machinery in the photoreceptor synapse of the mouse retina. We found dynamin, syndapin, amphiphysin, and calcineurin, a regulator of activity-dependent endocytosis, to be highly enriched around the active zone and the synaptic ribbon. We present evidence for two clathrin heavy chain variants in the photoreceptor terminal; one is enriched around the synaptic ribbon, whereas the other is localized in the entry region of the terminal. The focal enrichment of endocytic proteins around the synaptic ribbon is consistent with a focal uptake of endocytic markers at that site. This endocytic activity functionally depends on dynamin. These data propose that the presynaptic periactive zone surrounding the synaptic ribbon complex is a hotspot of endocytosis in photoreceptor ribbon synapses.

\section{Introduction}

Ribbon synapses are continuously active chemical synapses that are found, for example, in retinal photoreceptors and bipolar cells as well as in hair cells of the inner ear (for review, see Moser et al., 2006; Schmitz, 2009; Mercer and Thoreson, 2011). They differ from "conventional" synapses in several aspects. Ribbon synapses transmit graded changes of membrane potential into modulations of continuous, tonic exocytosis of synaptic vesicles (for review, see Heidelberger et al., 2005; Jackman et al., 2009; Mercer and Thoreson, 2011). To maintain synaptic transmission, ribbon synapses possess structural and functional specializations. The most prominent structural specialization is the synaptic ribbon, a large electron-dense presynaptic structure associated with large numbers of synaptic vesicles. In cross sections, ribbons usually appear bar shaped; three-dimensional representations reveal the plate-like, horseshoe-shaped structure of synaptic ribbons. RIBEYE is the only known protein specific to synaptic ribbons

Received Oct. 29, 2012; revised May 10, 2013; accepted May 14, 2013.

Author contributions: F.S. designed research; S.W., R.K., and F.S. performed research; S.W., R.K., and F.S. analyzed data; F.S. wrote the paper.

This work was supported by research Grants SFB894, TPA7, and GRK1326 from the German Research Community. We thank PD Dr. Elmar Krause for help with the SIM microscope (SFB894 platform project P1), PD Dr. Martin Jung (SFB894 platform project P3) for peptide synthesis, Dr. Jutta Schmitz-Kraemer for critically reading the manuscript, and Gabi Kiefer for excellent technical assistance.

Correspondence should be addressed to Dr. Frank Schmitz, Saarland University, Institute of Anatomy and Cell Biology, Department of Neuroanatomy, 66421 Homburg/Saar, Germany. E-mail: frank.schmitz@uks.eu.

DOI:10.1523/JNEUROSCI.5048-12.2013

Copyright $\odot 2013$ the authors $\quad 0270-6474 / 13 / 3310278-23 \$ 15.00 / 0$ and most likely is a major component of these structures (Schmitz et al., 2000, 2012). It belongs to the CtBP protein family. RIBEYE consists of a large unique N-terminal domain, the A domain, and a smaller C-terminal domain, the B domain, which is identical to CtBP2 (C-terminal binding-protein 2) except for the first 20 aa (Schmitz et al., 2000; for review, see Schmitz, 2009).

Photoreceptor synapses are located in the outer plexiform layer (OPL) of the retina. Rod photoreceptors contain single, large active zones with a single synaptic ribbon; cone synapses contain multiple active zones with multiple synaptic ribbons. The basal end of the synaptic ribbon is anchored to the active zone where synaptic vesicle exocytosis occurs (Zenisek et al., 2000). The active zone includes an electron-dense structure, the arciform density, which contains the active zone protein bassoon, as well as presynaptic L-type voltage-gated calcium channels (Schoch and Gundelfinger, 2006; for review, see tom Dieck and Brandstätter, 2006). Lateral to the presynaptic release sites, the periactive zone forms membrane pouches generated by invaginations of the dendritic tips of postsynaptic horizontal cells (for review, see Gray and Pease, 1971; Schmitz et al., 2012).

The continuous exocytosis at the ribbon synapse needs to be balanced by compensatory endocytosis to replenish vesicle pools. The rate of vesicle recycling is an important factor in the signaling at photoreceptor ribbon synapses (Jackman et al., 2009; Babai et al., 2010). Recent analyses indicated that synaptic ribbons have an important role in the resupply of release-ready synaptic vesicles (Spassova et al., 2004; Griesinger et al., 2005; Jackman et al., 2009; Babai et al., 2010; Frank et al., 2010; Schnee et al., 2011; Snellman 


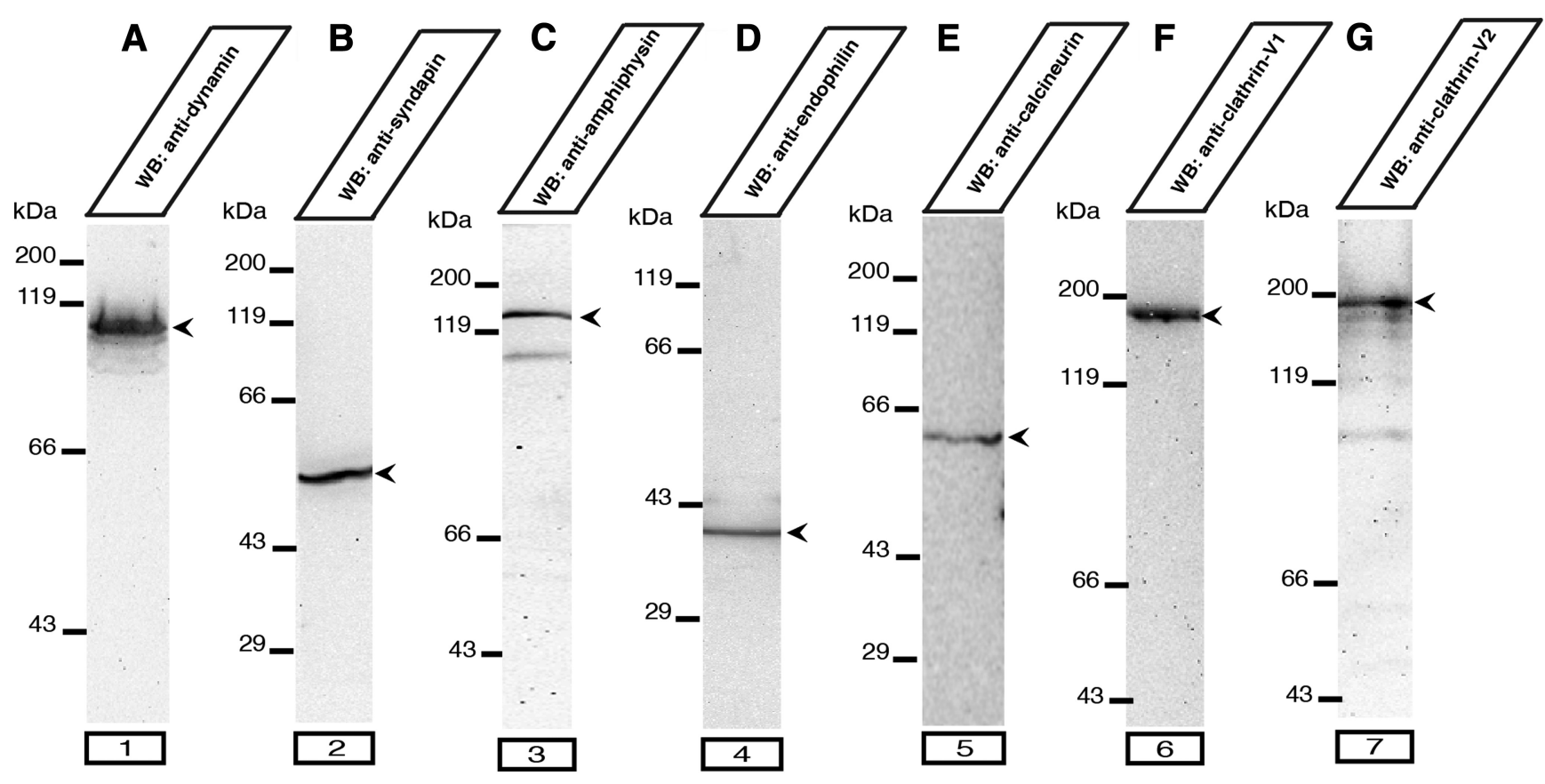

Figure 1. Expression of endocytic proteins in the mouse retina. $A-G$, Expression of endocytic proteins in extracts of the mouse retina as judged by Western blot analyses. All antibodies detect their respective antigen at the expected running position (indicated by arrowheads). In $\boldsymbol{A}-\boldsymbol{E}$, proteins were separated by $10 \%$ acrylamide SDS-PAGE; in $\boldsymbol{F}-\mathbf{G}$, by $8 \%$ acrylamide SDS-PAGE.

et al., 2011; Tian et al., 2012). How vesicle recycling is organized and accomplished in the ribbon synapse is still largely unclear. We applied super-resolution structured illumination microscopy (SR-SIM) and immunogold electron microscopy to localize key proteins of the recycling endocytic machinery in photoreceptor ribbon synapses. We found a local endocytic machinery highly enriched at the periactive zone in close vicinity to the synaptic ribbon. This periactive zone endocytic machinery is ideally placed to replenish the exocytotic machinery of the continuously active photoreceptor ribbon synapse.

\section{Materials and Methods \\ Antibodies}

Primary antibodies

Anti-RIBEYE(B)-domain/CtBP2 (U 2656) (Schmitz et al., 2000) polyclonal rabbit antiserum against RIBEYE(B)-domain was used for immunofluorescence staining in a 1:2000 dilution and for Western blotting in a 1:10,000 dilution (if not denoted otherwise).

Anti-CtBP2 (catalog \#612044, BD Transduction Laboratories) mouse monoclonal antibody raised against the $\mathrm{C}$-terminal amino acids 361-445 of CtBP2. This antibody detects RIBEYE [i.e., RIBEYE(B)-domain/ CtBP2] in Western blotting analyses and labels synaptic ribbons in immunofluorescence labeling analyses (Schwarz et al., 2011). This antibody was used for immunofluorescence labeling in a 1:500 dilution.

For the detection of dynamin, we used a well characterized protein G-purified monoclonal mouse antibody, anti-dynamin (hudy-1; Upstate antibodies, order \#05-319, Millipore) generated against a peptide (amino acids 822-838, SPDPFGPPPQVPSRPNR) in the proline-rich, C-terminal region of dynamin-1 (Hinshaw and Schmid, 1995; Takei et al., 1995; Warnock et al., 1995). Dynamin-1 is the predominant neuronspecific form of dynamin expressed in brain (Raimondi et al., 2011; for review, see Ferguson and De Camilli, 2012). The amino acid sequence of this peptide used for immunization is highly conserved between species in dynamin-1 (e.g., 100\% amino acid identity in man, mouse, pig, cow, and horse). The amino acid sequence of this peptide stretch is also conserved in dynamin-2, the ubiquitous, non-neuronal form of dynamin (70\% amino acid identity) and also in dynamin-3 (77\% amino acid identity). Dynamin-3 is also preferentially expressed in brain (as dynamin-1) but at much lower levels (Raimondi et al., 2011; for review, see Ferguson and De Camilli, 2012). The hudy-1 monoclonal antibody was denoted as an "anti-dynamin" antibody in Results. The corresponding blocking peptide was synthesized by Dr. Martin Jung (Department of Biochemistry and Molecular Biology, Saarland University, Homburg, Germany) and used for pre-absorption control experiments. The hudy-1 monoclonal antibody was applied for Western blotting and immunogold electron microscopy in a 1:1000 dilution and for immunostaining in a 1:500 dilution (if not denoted otherwise).

Anti-syndapin/pacsin (product \#196002, Synaptic Systems) polyclonal antiserum against syndapin-1/pacsin-1 was used for immunofluorescence microscopy in a 1:250 dilution, and for Western blotting in a 1:1000 dilution. The syndapin peptide was purchased from Synaptic Systems (196-0P) for pre-absorption control experiments.

Anti-amphiphysin (product \#120002, Synaptic Systems) was raised against a synthetic peptide (amino acids 2-15; ADIKTGIFAKNVQK) of amphiphysin-1. The antiserum was used for Western blotting in a 1:1000 dilution, and for immunostaining in a 1:250 dilution. The blocking peptide was purchased from Synaptic Systems (120-OP) for pre-absorption control experiments.

Anti-endophilin (product \#159002, Synaptic Systems) is a polyclonal antiserum raised against a synthetic peptide coding for amino acids $256-$ 276 of mouse endophilin-1 (QPKPRMSLEFATGDSTQ). For immunostaining, the antiserum was diluted 1:250, and for Western blotting, 1:1000. The endophilin peptide was also obtained from Synaptic Systems (159-0P) for pre-absorption (blocking) control experiments.

Anti-pan-calcineurin A antibody is an affinity-purified rabbit polyclonal antibody raised against a C-terminal peptide of calcineurin A (order number \#2614, Cell Signaling Technology via New England Biolabs). The antibody is purified by both protein A- and peptide-affinity chromatography. It was used for immunofluorescence microscopy in a 1:100 dilution, and for Western blotting in a 1:1000 dilution.

Anti-clathrin heavy chain (ab21679, abcam) is a polyclonal rabbit antibody raised against a peptide in the $\mathrm{C}$ terminus of human clathrin heavy chain. The blocking peptide (for pre-absorption control experiments) was also obtained from abcam (ab23440). This antibody detects clathrin heavy chain-variant 1 (CHC-V1) (see Results section) and was used for immunofluorescence microscopy and Western blotting in a 1:1000 dilution; for postembedding immunogold electron microscopy, it was diluted 1:250.

Anti-clathrin heavy chain (order \#P1663, Cell Signaling Technology via New England Biolabs), an affinity-purified rabbit antibody against a 
C-terminal peptide of human clathrin heavy chain, detects CHC-V1 (see Results section) and was used in a 1:250 dilution for immunofluorescence microscopy. The immunolabeling data on $\mathrm{CHC}-\mathrm{V} 1$ presented were obtained by immunolabeling with the above-mentioned antibody from abcam (abcam21679) against CHC-V1; but qualitatively identical immunolabeling results were obtained also with the anti-CHC-V1 antibody from Cell Signaling Technology (P1663) (data not shown).

Anti-clathrin heavy chain (ab59710, abcam) is a polyclonal rabbit antiserum that was raised against amino acids 619-638 (KAGLLQRALEHFTDLYDIKR) of rat clathrin heavy chain (100\% identical with mouse, highly conserved). For Western blotting, the antibody was diluted 1:1000, and for immunofluorescence labeling, 1:500. This antibody detects CHC-V2 (see Results section).

Anti-clathrin heavy chain (X22 mouse monoclonal antibody raised against clathrin heavy chain; Abcam) was raised against clathrin heavy chain purified from human brain (Brodsky, 1985). The antibody was used for immunofluorescence microscopy in a 1:100 dilution. This antibody detects CHC-V2 (see Results section).

Anti-panSV2, a monoclonal antibody against the synaptic vesicle protein SV2 (panSV2 monoclonal antibody, raised against all SV2 variants; Buckley and Kelly, 1985) was used to label the synaptic vesiclecontaining presynaptic terminals. The supernatant was collected from cultured hybridoma cells (obtained from the Developmental Studies Hybridoma Bank, University of Iowa) and used in a 1:20 dilution.

Anti-vesicular glutamate transporter 1 (VGLUT1; NeuroMAB, University of California, Davis, Davis, CA; clone N28/9), a mouse monoclonal antibody, raised against fusion protein encoding amino acids 493560 of the rat (VGLUT1). The antibody was used for immunofluorescence microscopy in a 1:500 dilution. VGLUT1 is a marker protein of glutamatergic synaptic vesicles (Wojcik et al., 2004).

Anti-VGLUT1 (order \#135302, Synaptic Systems). This rabbit polyclonal antibody was raised against amino acids $456-560$ of rat VGLUT1 and was used for immunofluorescence microscopy in a 1:500 dilution.

Anti-PSD-95 (NeuroMAB, University of California, Davis, Davis, CA; clone K28/43), a mouse monoclonal antibody raised against fusion protein encoding amino acids 77-299 of human PSD-95, was used in a 1:500 dilution for immunofluorescence microscopy.

Anti-PSD-95 (L667) is a rabbit polyclonal antibody raised against rat PSD-95 (Irie et al., 1997). This antibody was a gift from Dr. Thomas C. Südhof (Stanford University, Palo Alto, CA) and used in a 1:1000 dilution for immunofluorescence microscopy.

Anti-Bassoon (VAM-PS003, Stressgen), a mouse monoclonal antibody raised against fusion protein encoding amino acids $738-103$ of rat bassoon, was used in a 1:100 dilution for immunofluorescence microscopy.

Anti-Bassoon (order \#141002, Synaptic Systems) is a polyclonal rabbit antibody raised against a fusion protein encoding the C-terminal 330 aa of rat bassoon. The antibody was used for immunofluorescence microscopy in a 1:100 dilution.

Secondary antibodies (for immunofluorescence labeling)

The following secondary antibodies were used: chicken anti-mouseAlexa Fluor 488; donkey anti-rabbit-Alexa Fluor 568; goat anti-mouse
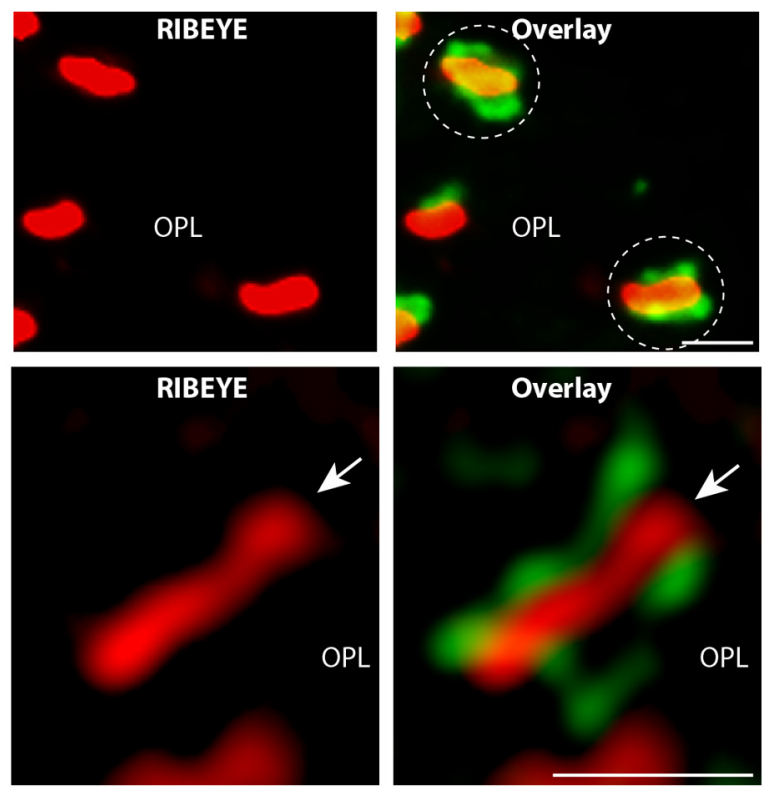

RIBEYE
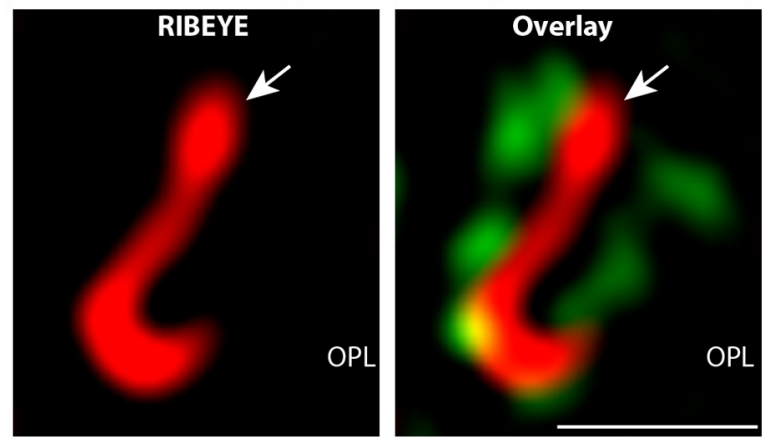

Figure 2. Distribution of dynamin in photoreceptor ribbon synapses at high resolution (immunolabeling of $0.5 \mu \mathrm{m}$ thin sections). $A, 0.5 \mu \mathrm{m}$ thin sections of the mouse retina were double immunolabeled with polyclonal antibodies against RIBEYE 2656) and mouse monoclonal antibodies against dynamin (hudy-1). Dashed circles in $\boldsymbol{A}$ denote single immunolabeled presyn作 ribbon (arrow). OPL, Outer plexiform layer. Scale bars, $1 \mu \mathrm{m}$.

Cy5; and goat anti-mouse-Alexa Fluor 488. All fluorophore-conjugated secondary antibodies were purchased from Invitrogen and were used in a 1:1000 dilution for $1 \mathrm{~h}$ at room temperature (RT) for immunolabeling experiments.

\section{Direct labeling of primary antibodies (mouse anti-CtBP2) with fluorophores (DyLight 488/DyLight 650)}

For triple-immunolabeling experiments, purified anti-CtBP2 mouse monoclonal antibody was conjugated with DyLight 488 (or DyLight 650) amine-reactive dye with the DyLight 488 Amine Reactive Dye Kit (catalog \#5302, Thermo Scientific)/DyLight 650 Microscale Antibody Labeling Kit (catalog \#84536, Thermo Scientific) according to the manufacturer's instructions. Twenty-five micrograms of purified antibody (in a volume of $100 \mu \mathrm{l}$ ) was dialyzed against a large volume of PBS in a Slide-A-Lyzer Mini Dialysis Units Plus Float kit (catalog \#66576, Thermo Scientific). Afterward, the antibody was coupled with the $N$-hydroxysuccinimide-activated DyLight 488/DyLight 650 compound exactly according to the manufacturer's instructions. DyLight 488 conjugated primary antibody against CtBP2 was used in a 1:20 dilution for immunolabeling. DyLight 650-conjugated primary antibody against CtBP2 was used in a 1:30 dilution for immunolabeling.

\section{Triple immunolabeling for SR-SIM}

For triple immunolabeling, we used a directly labeled mouse monoclonal antibody (CtBP2 antibody conjugated with either DyLight 488 or Dy- 

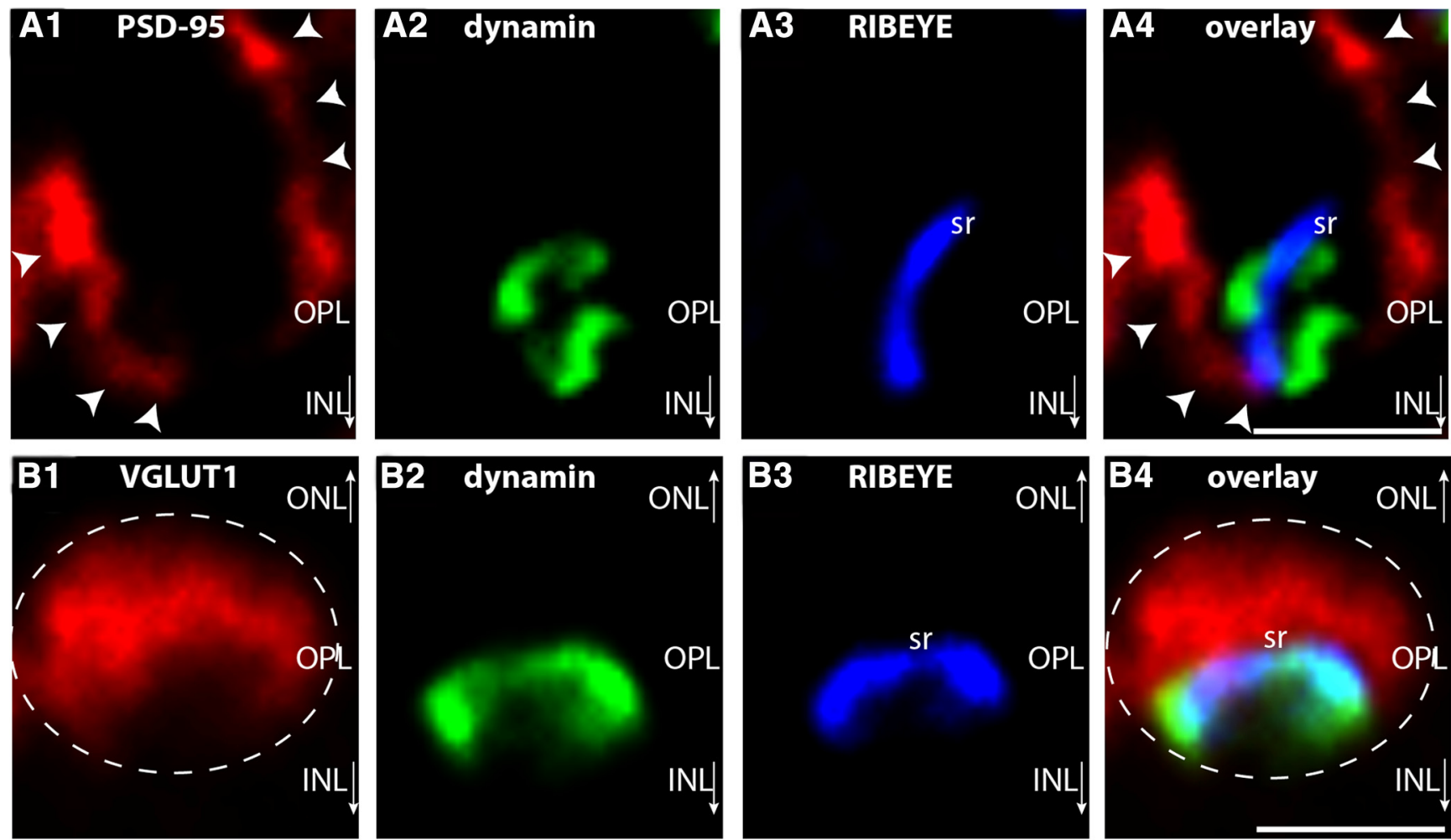

Figure 3. Localization of dynamin in relation to other synaptic proteins of the presynaptic photoreceptor terminal. $A, B$, The $0.5 \mu \mathrm{m}$ thin sections from mouse retina were triple immunolabeled with rabbit polyclonal antibodies against PSD-95 (L667) (A)/ or VGLUT1 (B), mouse monoclonal antibodies against dynamin (hudy-1) $(\boldsymbol{A}, \boldsymbol{B})$, and DyLight 650-direct labeled primary antibodies against RIBEYE(B)/CtBP2 ( $\boldsymbol{A}, \boldsymbol{B})$. In $\boldsymbol{A}$, the PSD-95 immunosignals label the presynaptic plasma membrane of the presynaptic terminals (Koulen et al., 1998; Aartsen et al., 2009), thus demarcating the extension of a single presynaptic terminal (arrowheads in $\boldsymbol{A}$ ). RIBEYE and dynamin are located close to each other at the distal end of the photoreceptor terminal that is facing the INL $(\boldsymbol{A})$. In $\boldsymbol{B}$, presynaptic terminals were immunolabeled with antibodies against VGLUT1, a marker protein of glutamatergic synaptic vesicles. Single-photoreceptor presynaptic terminals are indicated by the white dashed circles in $\boldsymbol{B}$. Similar as in $\boldsymbol{A}$, RIBEYE and dynamin are located close to each other at the distal border of the immunolabeled glutamatergic vesicles of the presynaptic terminal that faces the INL. ONL, Outer nuclear layer; OPL, outer plexiform layer; INL, inner nuclear layer; sr, synaptic ribbon. Arrows next to INL and ONL point into the direction of the respective layer. Scale bars, $1 \mu \mathrm{m}$.

Light 650, as indicated in the respective experiments) and two other primary antibodies (one from mouse, the second from rabbit, as indicated in the respective experiments), which were not directly fluorophore labeled. First, sections were incubated with the two unlabeled primary antibodies at the same time overnight (at the dilutions given above). On the next day, sections were washed three times with PBS and afterward were incubated with the respective secondary antibodies (goat antimouse-Cy5; and donkey anti-rabbit-Alexa Fluor 568 or donkey antirabbit Alexa Fluor 568 and chicken anti-mouse Alexa Fluor 488). After $1 \mathrm{~h}$ incubation, sections were washed again three times with PBS and finally incubated with the directly DyLight 488/DyLight 650-labeled CtBP2 primary antibody (in the dilutions summarized above) overnight at $4^{\circ} \mathrm{C}$. After overnight incubation, sections were washed three times with PBS and embedded with antifade solution containing $n$-propyl gallate, as previously described (Schmitz et al., 2000).

\section{Blocking of antibodies: preabsorption experiments}

For pre-absorption blocking experiments, antisera were diluted to their indicated respective working concentrations. To these antibody dilutions either the specific blocking peptide $(20 \mu \mathrm{g})$ or an unrelated peptide (same amount) was added. These mixtures were incubated overnight on a turning wheel and were used on the other day for immunolabeling experiments, as described below.

All experiments were performed with mouse retinas of either sexes. Mice were killed in the early afternoon. Eyes were collected at environmental daylight conditions (luminance of $\approx 2 \mathrm{~cd} / \mathrm{m}^{2}$ ). Data similar to those shown for the mouse retina were also obtained with the bovine retina (of either sexes; data not shown).

\section{Immunofluorescence microscopy}

Immunolabeling of $0.5 \mu \mathrm{m}$ thin resin sections

Embedding procedure. The preparation procedure for sample embedding into EPON resin is a modification from the procedure described by Drenckhahn and Franz (1986). In brief, tissue was flash frozen in liquid nitrogen-cooled isopentane. Then, as a modification of the original procedure, lyophilization of the tissue was performed while the tissue was continuously cooled by liquid nitrogen. Lyophilization of the samples was typically performed in a vacuum of $\approx 10^{-7} \mathrm{mbar}\left(10^{-5} \mathrm{~Pa}\right)$ using a TCP270 turbomolecular pump (Arthur-Pfeiffer-Vacuumtechnik) controlled by a PKG020 Pirani-gold cathode gauge control unit and an oil diffusion pump as a pre-pumping unit (type DUO 004B, ArthurPfeiffer-Vacuumtechnik). Samples were lyophilized in liquid nitrogen for $\approx 24 \mathrm{~h}$. Afterward, samples were equilibrated to room temperature, infiltrated with EPON resin and degassed for $24 \mathrm{~h}$ to ensure complete penetration with EPON. Curing of the resin-embedded samples was performed at $60^{\circ} \mathrm{C}$ for $\approx 24 \mathrm{~h}$.

Immunolabeling procedure for use with $0.5 \mu \mathrm{m}$ thin resin sections. Immunofluorescence labeling experiments were performed with semithin sections (thickness, $\approx 0.5 \mu \mathrm{m}$ ) to obtain optimal resolution. The usefulness of semithin sections to obtain images with nanoscale resolution has been previously demonstrated by Punge et al. (2008). From the tissue blocks, $0.5 \mu \mathrm{m}$ thin sections were cut with a Reichert ultramicrotome. EPON resin was removed by the procedure of Mayor et al. (1961) with slight modifications. In brief, EPON resin was removed by incubating the sections in the following solutions: sodium methanolate [ $30 \%$ solution in methanol (MERCK) for $10 \mathrm{~min}$ ]; $1: 1$ mixture of xylol/methanol (10 min); acetone ( $2 \times 10 \mathrm{~min}) ; \mathrm{H}_{2} \mathrm{O}(10$ $\mathrm{min}$ ); and PBS (10 min). Afterward, sections were incubated with the 

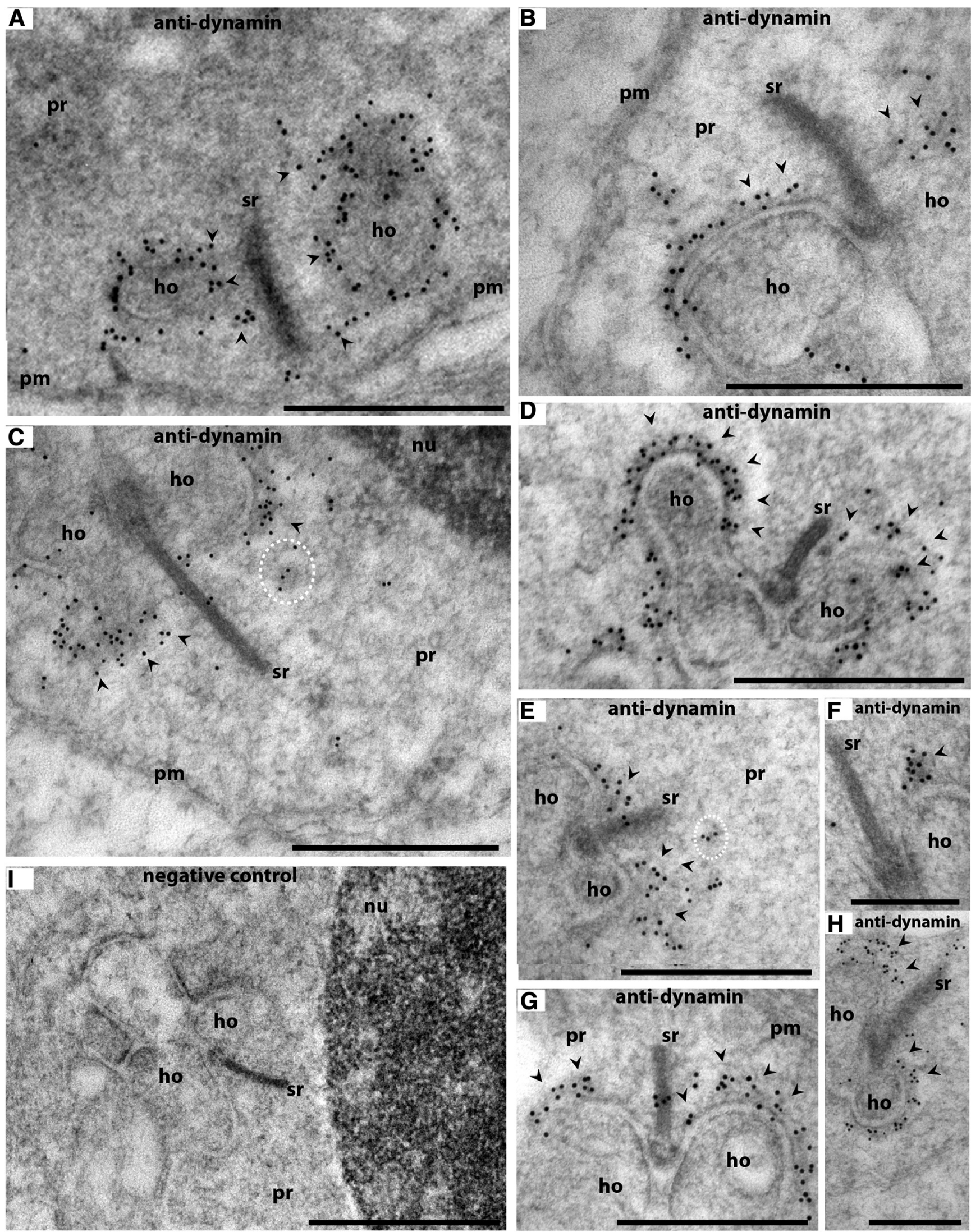

F anti-dynamin

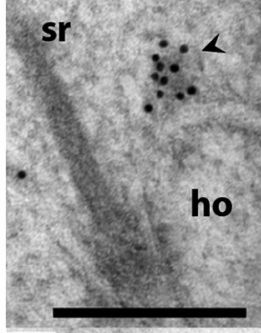

H anti-dynamin

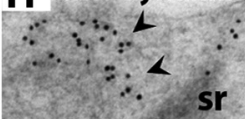

ho

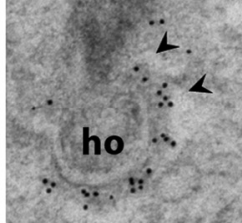

Figure 4. Postembedding immunogold labeling of photoreceptor synapses of the mouse retina with dynamin antibodies. $\boldsymbol{A}-\boldsymbol{H}$, Ultrathin sections immunolabeled with mouse monoclonal antibodies against dynamin (hudy-1). Binding of the primary antibodies was detected with goat anti-mouse antibodies conjugated to $10 \mathrm{~nm}$ gold particles. The dynamin immunogold label is highly enriched at the presynaptic plasma membrane surrounding the synaptic ribbon (arrowheads in $\boldsymbol{A}-\boldsymbol{H}$ ). This dynamin immunogold label at the periactive zone was particularly strong at the lateral presynaptic plasma membrane pouches opposite to dendritic tips of postsynaptic horizontal cells (ho). I, A control incubation in which only secondary antibody (but no primary antibody) was applied. No immunosignal was observed under these incubations, further stressing the specificity of the immunolabeling results. A quantitative minor portion of (Figure legend continues.) 
respective primary and secondary antibodies as described above (Schmitz et al., 2000; Alpadi et al., 2008).

Control incubations. Control incubations for immunolabeling experiments were performed by omitting the primary antibody and only incubating with the secondary antibody. No immunofluorescent signal was observed in photoreceptor synapses in these control incubations. In further control experiments, antibodies were preabsorbed with the respective antigen as described below and processed for immunolabeling.

Super-resolution structured illumination microscopy. To further improve the spatial resolution of our immunolabeling data, we applied multicolor 3D-SR-SIM analyses (Schermelleh et al., 2008). The resolution of normal microscopy is limited to $\approx 200 \mathrm{~nm}$ in lateral $(x, y)$ and $\approx 500 \mathrm{~nm}$ in axial $(z)$ direction. Super-resolution structured illumination microscopy or SR-SIM gives the possibility of exceeding this diffraction limit. SR-SIM increases the normal lateral resolution by a factor of two, and 3D-SR-SIM provides the same increase in axial direction. Another advantage of the SR-SIM is the possibility of using standard dyes and staining protocols (for review, see Schermelleh et al., 2010). For structured illumination microscopy, the ELYRA PS1 setup, as well as a precursor prototype, from Zeiss were used. Images were taken with a $63 \times$ Plan-Apochromat (numerical aperture, 1.4) with excitation light wavelengths of 488,561, and $635 \mathrm{~nm}$, and then processed for structured illumination microscopy to obtain higher resolutions (Gustafsson et al., 2008; for review, see Schermelleh et al., 2010). $Z$-stacks with an interval of $150 \mathrm{~nm}$ were used to scan the whole retina section for 3D-SR-SIM (Schermelleh et al., 2008; for review, see Schermelleh et al., 2010). For acquisition and processing as well as for 3D reconstruction and maximum projection, the Zen2010 software (Zeiss) was used. For imaging analysis, sections were oversampled to exclude signal loss; for 3D reconstruction, only relevant image planes were used. For the 3D reconstruction, the transparent mode was applied.

In general, there is a potential risk of projection artifacts using SR-SIM due to chromatic aberration (Schermelleh et al., 2008). The Zeiss setup that was used was corrected for chromatic aberration in $x$-, $y$-, and $z$-directions using multicolor beads, and all obtained images were examined considering this problem. Identical imaging results were obtained if different fluorophores were used for imaging.

\section{Postembedding immunogold electron microscopy}

Tissue embedding and immunogold labeling procedure. Tissue embedding and immunogold labeling was performed as previously described (Schmitz et al., 2000) with some modifications. In brief, freshly isolated mouse retinas were fixed in $0.05 \%$ glutaraldehyde, $2 \%$ freshly depolymerized paraformaldehyde in $\mathrm{PBS}, \mathrm{pH} 7.4$, for $2 \mathrm{~h}$ at $4^{\circ} \mathrm{C}$. After several washes with $\mathrm{PBS}$, followed by $\mathrm{H}_{2} \mathrm{O}$, samples were treated with tannic acid $\left(0.1 \%\right.$, w/v, in $\left.\mathrm{H}_{2} \mathrm{O}\right)$ for $1 \mathrm{~h}$ at $4^{\circ} \mathrm{C}$. Samples were washed with $\mathrm{H}_{2} \mathrm{O}$ and incubated for $2 \mathrm{~h}$ in $1 \%$ uranyl acetate $\left(\right.$ in $\left.\mathrm{H}_{2} \mathrm{O}\right)$. Subsequently, probes were dehydrated in an ascending concentration of ethanol. At 30\% ethanol, samples were transferred from $4^{\circ} \mathrm{C}$ to $-20^{\circ} \mathrm{C}$ to minimize extraction of lipids and were kept at $-20^{\circ} \mathrm{C}$ during the entire embedding procedure. Dehydration was performed in steps of 30\%, 50\%, 70\%, 80\%, $90 \%$, and $98 \%$ ethanol (each for $\approx 30 \mathrm{~min}$ ). Afterward, samples were infiltrated with London Resin (LR)-Gold (Electron Microscopic Sciences) to which $2 \%$ of $\mathrm{H}_{2} \mathrm{O}(\mathrm{v} / \mathrm{v})$ had been added. LR-gold solution was changed thrice and finally replaced by LR-gold $/ 2 \% \mathrm{H}_{2} \mathrm{O}$ resin solution that contained $0.1 \%$ benzil as a polymerization catalyst. Polymerization

\footnotetext{
$\leftarrow$

(Figure legend continued.) dynamin immunolabel was found in a cytosolic localization within the presynaptic terminal (dashed circles in $($ and $\boldsymbol{E}$ ). This minor portion could result from either labeling of endomembranes or tangential views of dynamin on periactive zone of lateral pouches above the section plane. Please note that a postembedding protocol was used for immunolabeling. In postembedding protocols, no osmium tetroxide can be used. Therefore, lipid-rich membrane compartments (i.e., synaptic vesicles) remain invisible with postembedding methods. pr, Presynaptic terminal; sr, synaptic ribbon; pm, extrasynaptic plasma membrane (outside of the presynaptic plasma membrane invagination with no contact to the postsynaptic cavity; see also Fig. 17); nu, nucleus. Black arrowheads point to dynamin immunogold particles close to the synaptic ribbons. Scale bars: $A-E, G, I, 500 \mathrm{~nm} ; \boldsymbol{F}, \boldsymbol{H}, 200 \mathrm{~nm}$.
}

was performed at $-20^{\circ} \mathrm{C}$ with UV light (for $\approx 24 \mathrm{~h}$ ). For immunolabeling, ultrathin sections $(50-80 \mathrm{~nm}$ in thickness) were first treated with $0.5 \%$ bovine serum albumin (BSA) in PBS for $45 \mathrm{~min}$ at RT to block nonspecific protein binding sites. Then, primary antibodies [dynamin (hudy-1), clathrin (CHC-V1; ab21679)] were applied overnight in a 1:250 dilution in $0.5 \%$ BSA/PBS. After several washes with PBS, binding of the primary antibody was detected with goat anti-mouse/goat antirabbit secondary antibody conjugated to $10 \mathrm{~nm}$ gold particles (Sigma). Afterward, immune complexes were fixed with $2.5 \%$ glutaraldehyde in PBS for 15 min at RT. Sections were contrasted with $2 \%$ uranylacetate in $\mathrm{H}_{2} \mathrm{O}$ and analyzed with a Tecnai Biotwin digital transmission electron microscope (FEI). As negative controls, either primary antibodies were omitted and/or unrelated antibodies were used. Please note that a postembedding protocol was used. In postembedding protocols, no osmium tetroxide can be used to enhance membrane contrast. Lipid-rich membrane compartments (i.e., synaptic vesicles) remain largely invisible with that method.

Isolation of photoreceptors from the mature mouse retina. Photoreceptor cells from the mature retina were isolated by gentle enzymatic digestion with papain, largely as previously described (TownesAnderson et al., 1985, 1988; Rebrik and Korenbrot, 2004) with some modifications. In brief, retinas were isolated from adult mice within 5 min postmortem (in ambient light). The enucleated eyes were bisected at the equatorial plane, and the posterior eye cup transferred into ice-cold low- $\mathrm{Ca}^{2+}$-containing saline solution (abbreviated as "LCS" solution) containing the following: $132 \mathrm{~mm} \mathrm{NaCl}, 3 \mathrm{~mm} \mathrm{KCl}, 1$ $\mathrm{mm} \mathrm{MgCl}_{2} \times 6 \mathrm{H}_{2} \mathrm{O}, 0.5 \mathrm{~mm} \mathrm{CaCl}, 10 \mathrm{~mm}$ sodium pyruvate, $10 \mathrm{~mm}$ glucose, $10 \mathrm{~mm}$ HEPES, pH $7.4(\approx 300 \mathrm{mOsm} / \mathrm{L})$. LCS was saturated with $5 \% \mathrm{CO}_{2} / 95 \% \mathrm{O}_{2}$ before use. From the posterior eyecup, the neural retina was gently peeled off from the pigment epithelium and incubated in $1 \mathrm{ml}$ of cysteine-activated papain solution [containing 9 $\mathrm{U} / \mathrm{ml}$ papain (catalog \#76220-25G, Sigma); $2.7 \mathrm{~mm}$ L-cysteine (cata$\log \# 1693.1$, Roth) in LCS] for $20 \mathrm{~min}$ at $25^{\circ} \mathrm{C}$. Activation of papain $(9$ $\mathrm{U} / \mathrm{ml}$ ) was done by preincubation with L-cysteine (2.7 $\mathrm{mm}$ in LCS) at $37^{\circ} \mathrm{C}$ for $20 \mathrm{~min}$. After removing the papain solution, the retina was gently washed three times with $1 \mathrm{ml}$ of LCS solution containing $2 \%$ FCS and $0.01 \mathrm{mg} / \mathrm{ml}$ DNase (catalog \#DN25-110MG, Sigma). To dissociate photoreceptor cells, papain-treated retina was gently triturated (three to four times) with a wide-bore plastic Pasteur pipette. The resulting cell suspension was plated on concanavalin A $(250 \mathrm{mg}$; catalog \#C7275, Sigma)-coated coverslips. For the coating of $25 \mathrm{~mm}$ round coverslips, $\approx 200 \mu \mathrm{l}$ of $1 \mathrm{mg} / \mathrm{ml}$ concanavalin A (in LCS solution) was added for $1 \mathrm{~h}$ at RT. Unbound concanavalin A was removed by three washes with LCS before the experiments. Cells were allowed to settle on the coverslips for $30 \mathrm{~min}$ at $37^{\circ} \mathrm{C}$ for tight attachment.

For immunocytochemistry, cells were washed once with LCS and fixed with $4 \%$ paraformaldehyde in PBS for 15 min at RT. Fixed cells were washed three times with PBS and then permeabilized with $0.1 \%$ saponin (S4521-10G, Sigma) in PBS for 15 min at RT. After permeabilization, cells were treated with $1 \%$ BSA $/ 0.1 \%$ saponin in PBS for 45 min and were incubated with primary antibodies (i.e., hudy-1, 1:250; and U2656, 1:1000) overnight at $4^{\circ} \mathrm{C}$. After three washes with PBS, cells were simultaneously incubated for $1 \mathrm{~h}$ at RT with secondary antibodies, chicken anti-mouse-Alexa Fluor 488 and donkey anti-rabbit-Alexa Fluor 568. After washing with PBS, coverslips were mounted on glass cover slides with antifade solution and sealed with nail polish.

For conventional transmission electron microscopy, mouse photoreceptor cells isolated as described above, were processed and embedded exactly as previously described (Schoch et al., 2006). Ultrathin sections were analyzed with a Tecnai Biotwin 12 transmission electron microscope (FEI).

\section{Analysis of synaptic ribbon-associated endocytic activity in synaptic terminals of isolated mouse photoreceptors}

Endocytic activity of isolated photoreceptors was visualized with sulforhodamine 101 (SR101) (S7635, Sigma), a fluid-phase endocytic marker (Lichtman et al., 1985; Keifer et al., 1992; Teng et al., 1999; Takahashi et al., 2002; Euler et al., 2009) or with the fixable SR101 analog Texas Red-hydrazide (T6256, Invitrogen) (Nimmerjahn et al., 2004). 


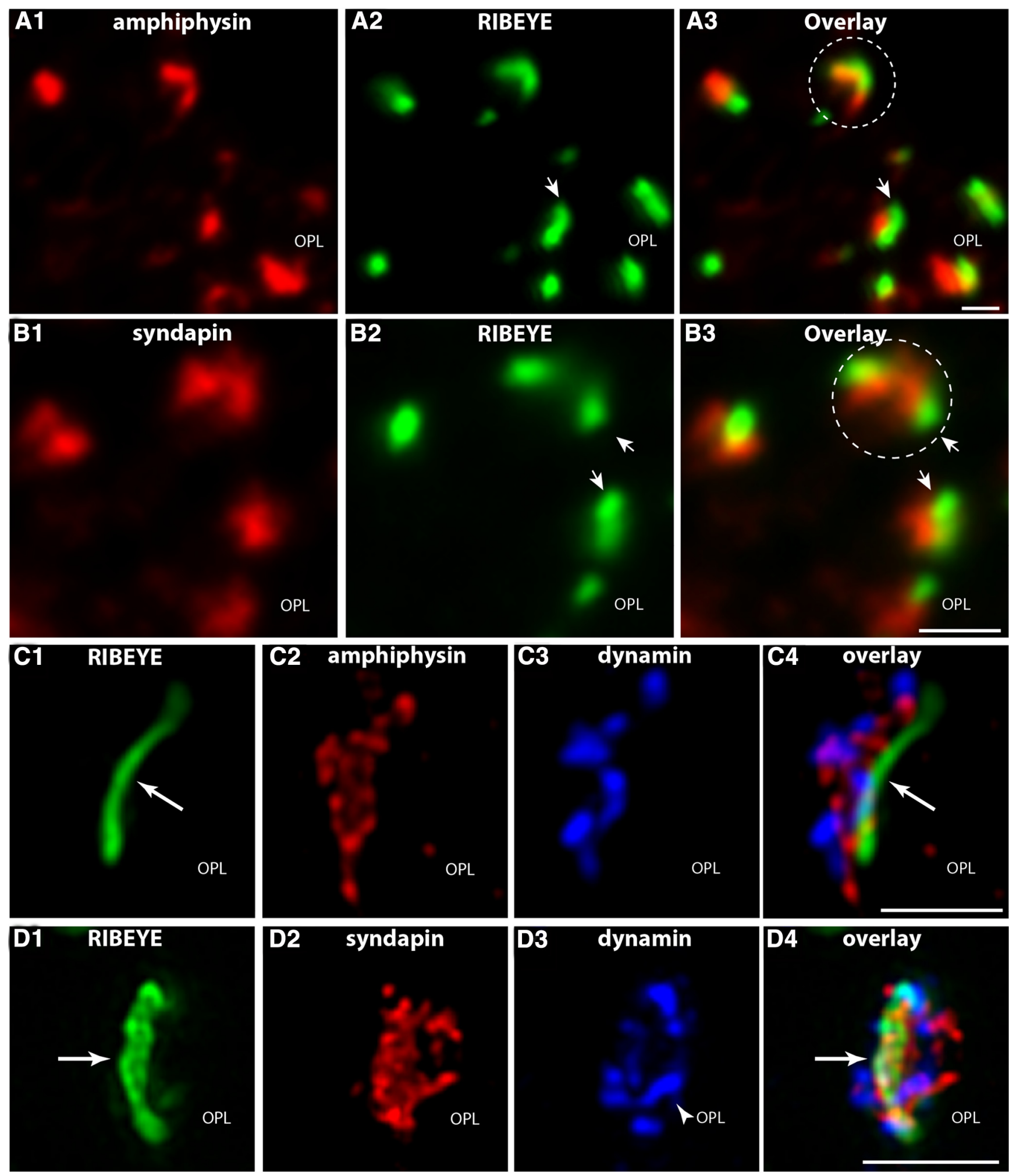

Figure 5. $A, B$, Distribution of amphiphysin and syndapin in photoreceptor ribbon synapses at high resolution (conventional imaging). $A, B$, The $0.5 \mu \mathrm{m}$ thin sections of the mouse retina were double immunolabeled with polyclonal antibodies against amphiphysin and mouse monoclonal antibodies against RIBEYE(B)-domain/CtBP2 (in $A$ ), and polyclonal antibodies against syndapin and mouse monoclonal antibodies against RIBEYE(B)-domain/CtBP2 (in $\boldsymbol{B}$ ). Arrows point to immunolabeled synaptic ribbons. Dashed circles in $\boldsymbol{A}$ and $\boldsymbol{B}$ denote single-immunolabeled presynaptic terminals/synaptic ribbon complexes of rod photoreceptors. C, D, Multicolor, 2D-SR-SIM analyses of the distribution of amphiphysin and syndapin in photoreceptor synapses. In $\boldsymbol{C}$ and $\boldsymbol{D}, 0.5 \mu \mathrm{m}$ thin sections of the mouse retina were triple immunolabeled with Alexa Fluor 488 directly labeled mouse monoclonal antibody against RIBEYE(B)-domain/CtBP2, rabbit polyclonal antibody against amphiphysin $(\boldsymbol{C})$ or syndapin $(\boldsymbol{D})$ and mouse monoclonal antibody against dynamin $(\boldsymbol{C}, \boldsymbol{D})$. Arrows point to immunolabeled synaptic ribbons. OPL, Outer plexiform layer. Scale bars, $1 \mu \mathrm{m}$. 

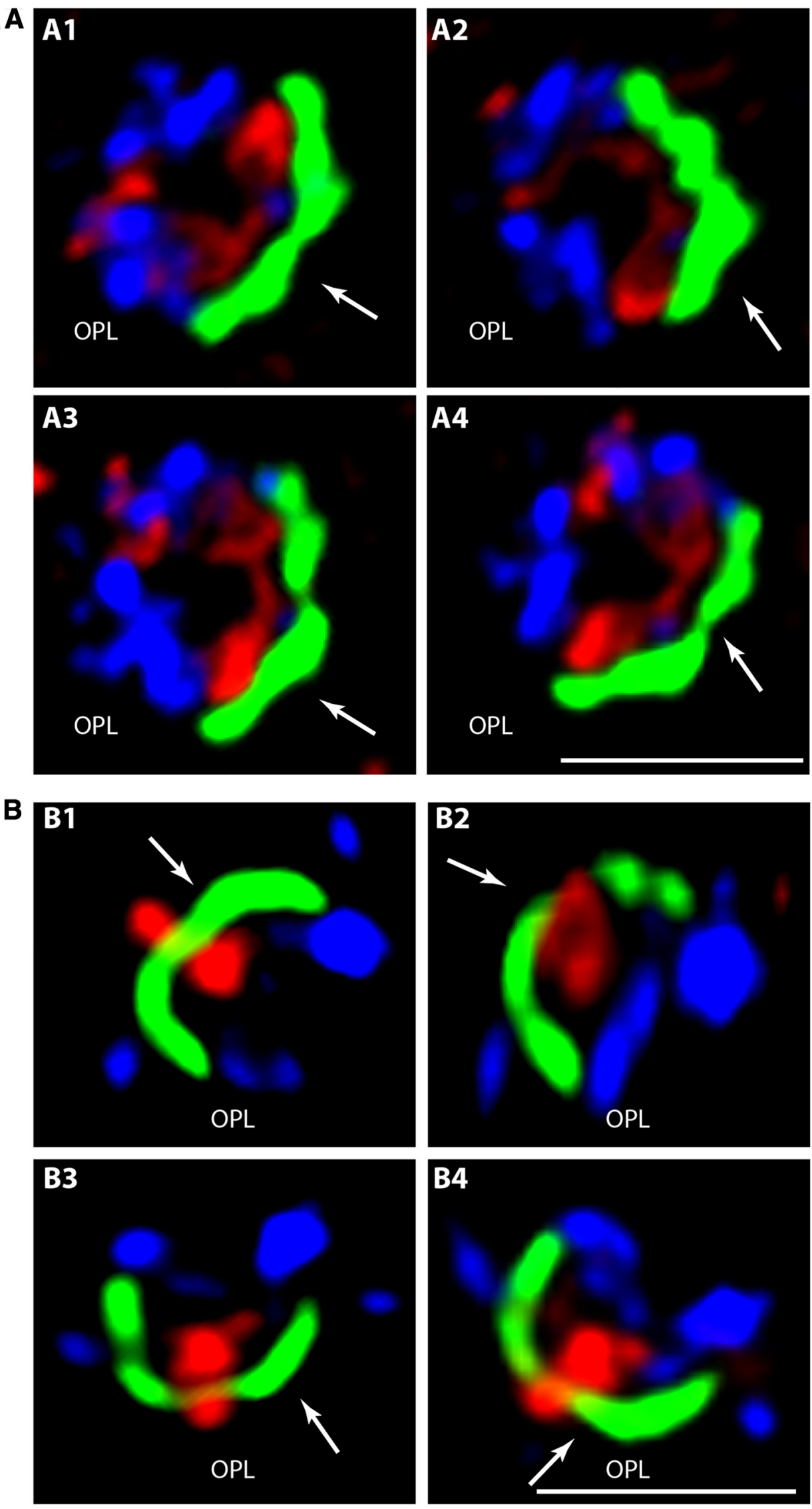

3D-SR-SIM analyses:

RIBEYE/amphiphysin/

dynamin

(triple immunolabelling)

\section{RIBEYE amphiphysin dynamin}

\section{D-SR-SIM analyses:}

RIBEYE/syndapin/

dynamin

(triple immunolabelling)

\section{RIBEYE syndapin dynamin}

Figure 6. Multicolor3D-SR-SIM ofRIBEYE, dynamin, and syndapin/amphiphysin in theactivezone of single rod photoreceptor synapses. In A, triple-immunolabeling 3D-SR-SIManalyseswereperformed with antibodies against RIBEYE, dynamin, and amphiphysin; in B, triple-immunolabeling 3D-SR-SIM analyses were performed with antibodies against RIBEYE, dynamin, and syndapin ( $A 1-A 4$ and $B 1-B 4$, respectively), denoting different lateral views of the same single-immunolabeled synaptic ribbon of a rod photoreceptor synapse. Arrows denote the immunolabeled synaptic ribbon. OPL,Outer plexiform layer. Scale bars, $1 \mu \mathrm{m}$. 

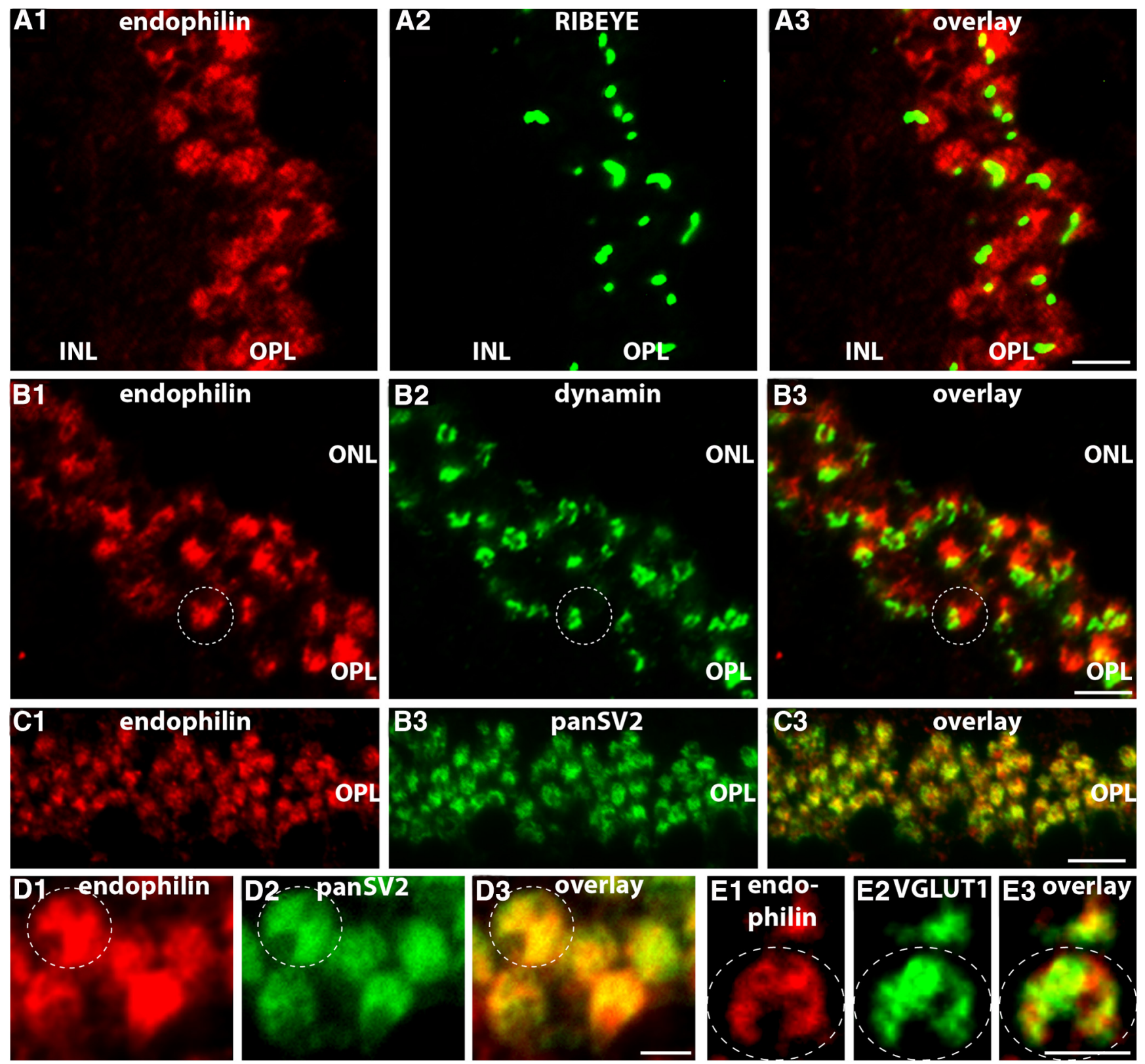

Figure 7. Localization of endophilin in photoreceptor synapses of the mouse retina. $A$, The $0.5 \mu \mathrm{m}$ thin sections of the mouse retina were double immunolabeled with rabbit polyclonal antibodies against endophilin and mouse monoclonal antibodies against RIBEYE(B)-domain/CtBP2. B, The $0.5 \mu \mathrm{m}$ thin sections of the mouse retina were double immunolabeled with rabbit polyclonal antibodies against endophilin and mouse monoclonal antibodies against dynamin. $\boldsymbol{C}, \boldsymbol{D}$, The $0.5 \mu \mathrm{m}$ thin sections of the mouse retina were double immunolabeled with rabbit polyclonal antibodies against endophilin and mouse monoclonal antibodies against the synaptic vesicle protein 2 (panSV2; detecting all SV2 isoforms). $\boldsymbol{E}$, The $0.5 \mu \mathrm{m}$ thin sections of the mouse retina were double immunolabeled with rabbit polyclonal antibodies against endophilin and mouse monoclonal antibodies against VGLUT1. Dashed circles in $\boldsymbol{B}, \boldsymbol{D}$, and $\boldsymbol{E}$ denote single presynaptic photoreceptor terminals. Endophilin is diffusely distributed throughout the presynaptic terminal and is not particularly enriched around the synaptic ribbon. All micrographs were obtained by conventional imaging. ONL, Outer nuclear layer; OPL, outer plexiform layer; INL, inner nuclear layer. Scale bars: $\boldsymbol{A}, 10 \mu \mathrm{m} ; \boldsymbol{B}, 5 \mu \mathrm{m} ; \boldsymbol{C}, 12 \mu \mathrm{m} ; \boldsymbol{D}, \boldsymbol{E}, 1 \mu \mathrm{m}$.

Isolated mouse photoreceptors, prepared as described above, were incubated for $2 \mathrm{~min}$ at room temperature with $1 \mu \mathrm{M}$ SR101/Texas Redhydrazide. SR101/Texas Red-hydrazide was dissolved in LCS containing $2 \mathrm{~mm} \mathrm{Ca}^{2+}$. SR101/Texas Red-hydrazide-loading experiments resulted in virtually identical labeling results in isolated mouse photoreceptors (see Fig. 16) (data not shown). The immunolabeling results shown in Figure 16 were obtained after loading with fixable SR101 (Texas Red-hydrazide). After labeling, photoreceptors were rinsed three times with LCS. To analyze the importance of dynamin in ribbon-associated endocytosis, photoreceptors were incubated for 30 $\min$ at $37^{\circ} \mathrm{C}$ with $100 \mu \mathrm{M}$ dynasore, a specific blocker of dynamin activity (Macia et al., 2006; Kirchhausen et al., 2008; Van Hook and Thoreson, 2012), before incubation with sulforhodamine/Texas Red- hydrazide. After labeling and three short washes with LCS, photoreceptors were fixed with 4\% PFA for $15 \mathrm{~min}$ at RT and processed for immunolabeling as described above.

\section{Western blots}

Western blot analyses were performed as previously described (Schmitz et al., 2000) using the indicated antibodies at the indicated dilutions. Binding of the primary antibodies was detected with secondary antibodies conjugated with horseradish peroxidase and enhanced chemoluminescence (ECL). ECL signals of the antibody-incubated Western blots were scanned and documented with a Bio-Rad gelDoc Chemoluminescence detection system. As molecular weight standards for SDS PAGE, we used a prestained protein ladder (order \#26616, Thermo Scientific), 

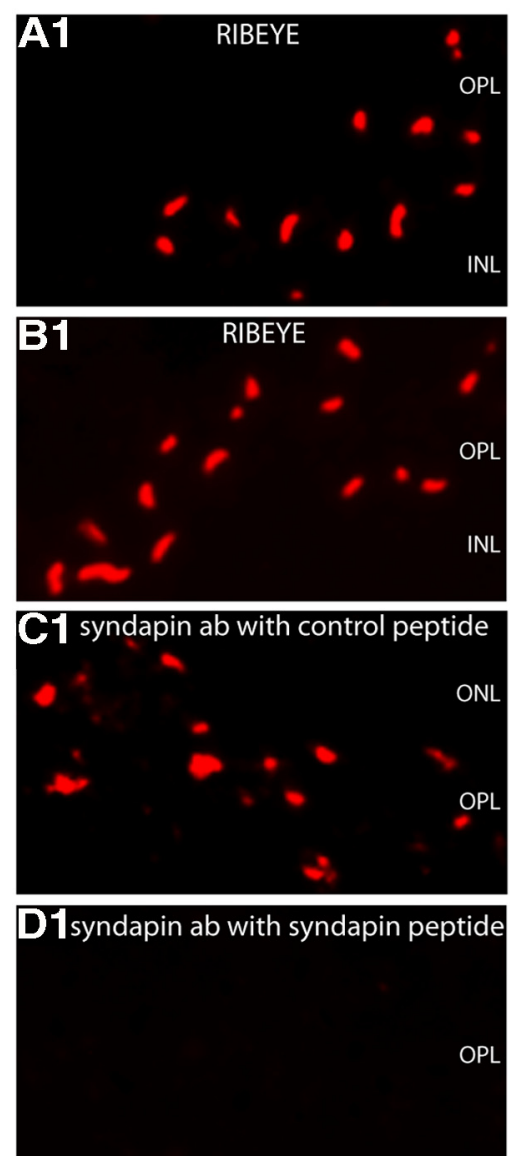

E1 amphiphysin with control peptide

OP

INL

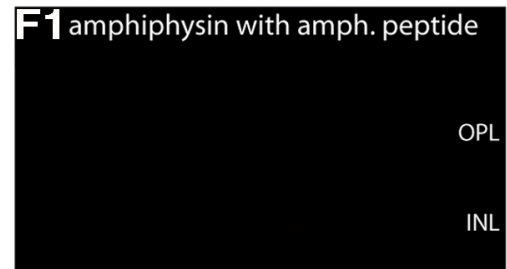

G1 endophilin with control peptide

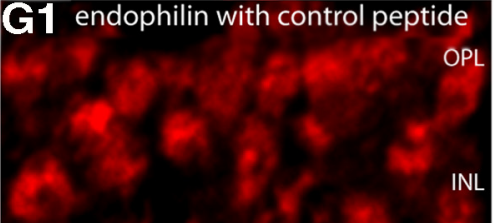

H1 endophilin with endoph. peptide

OPL

INL

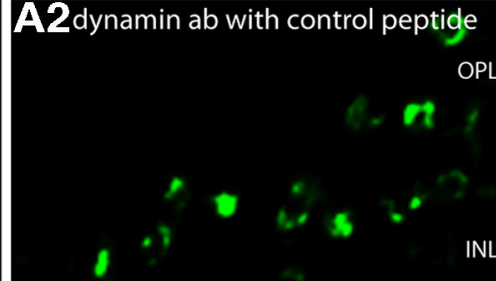

B2dynamin ab with dynamin peptide
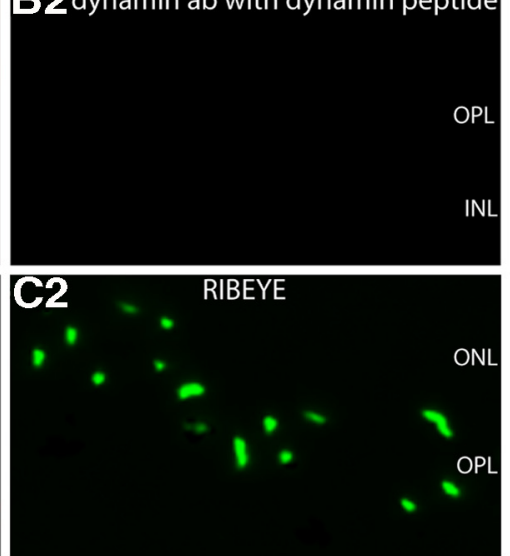

\section{D2}
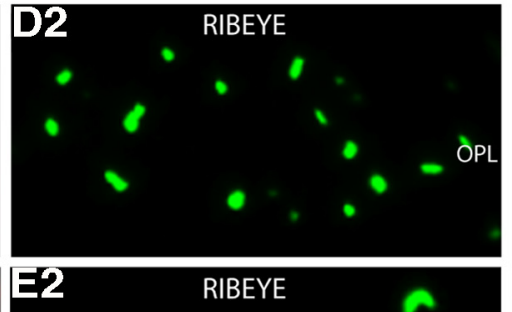

RIBEYE
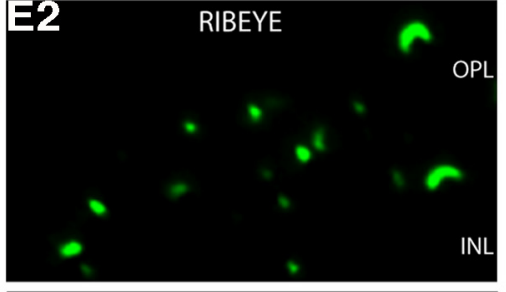

\section{$F 2$}

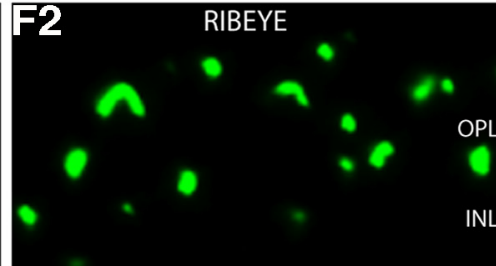

\section{G2}

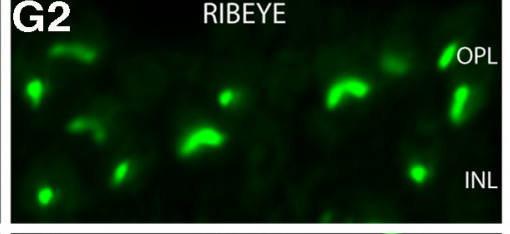

\section{$\mathrm{H2}$}
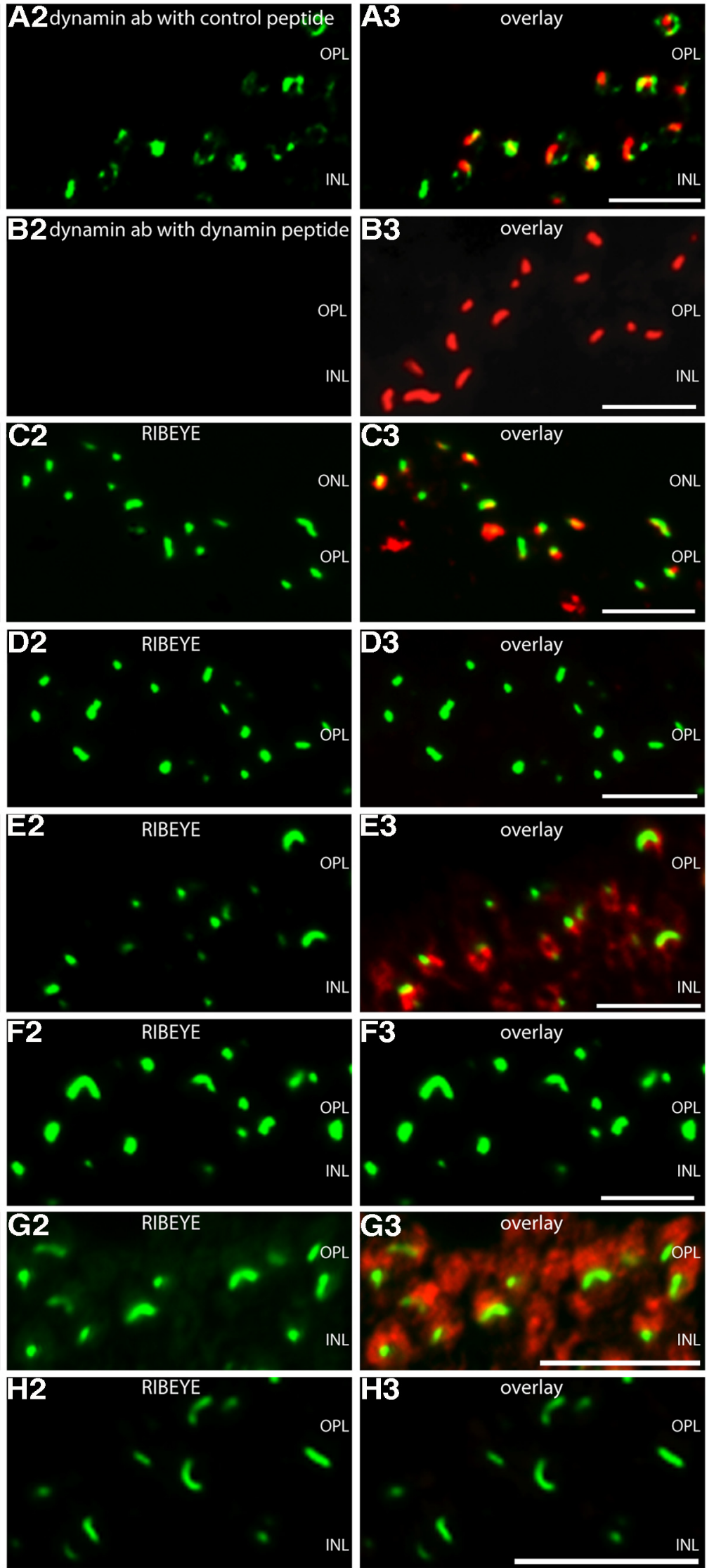

H3

overlay

OPL
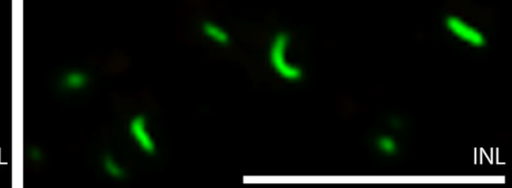

Figure 8. Pre-absorption control experiments for the immunolabeling analyses. $\boldsymbol{A}-\boldsymbol{H}$, Double immunolabeling of $0.5 \mu \mathrm{m}$ thin mouse retinal sections with the indicated antibodies preabsorbed with either their specific peptide used for immunization $(\boldsymbol{B}, \boldsymbol{D}, \boldsymbol{F}, \boldsymbol{H})$ or with an unrelated control peptide $(\boldsymbol{A}, \boldsymbol{C}, \boldsymbol{E}, \boldsymbol{G})$. To visualize ribbon synapses, sections were coimmunolabeled with either rabbit polyclonal antibodies against RIBEYE (U2656 in $A$ and $B$ ) or mouse monoclonal antibodies against RIBEYE(B)-domain/CtBP2. Preabsorption with the specific peptide completely blocked the (Figure legend continues.) 

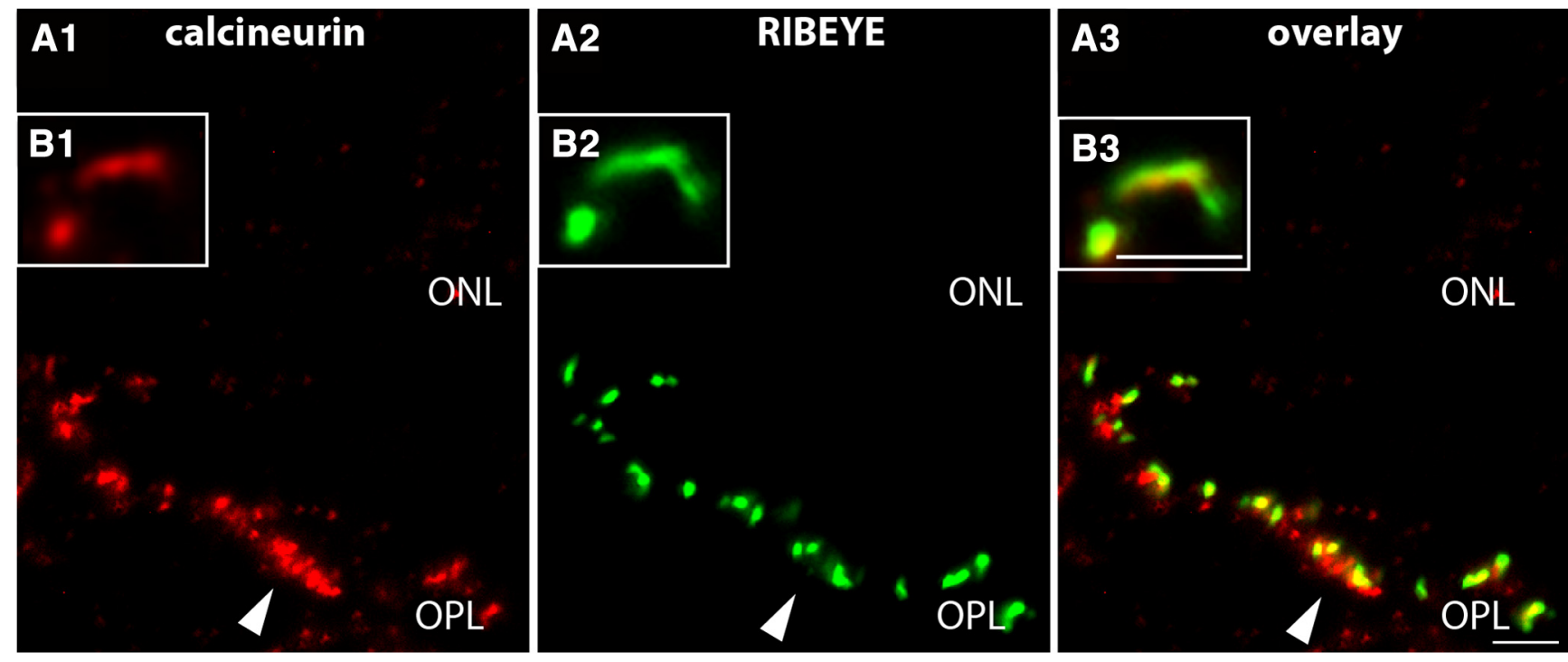

Figure 9. The $\mathrm{Ca}^{2+}$-binding phosphatase calcineurin, a $\mathrm{Ca}^{2+}$ sensor of endocytosis, is enriched at the synaptic ribbon. $\boldsymbol{A}$, The $0.5 \mu \mathrm{m}$ thin sections of the mouse retina were double immunolabeled with affinity-purified rabbit polyclonal antibodies against calcineurin and mouse monoclonal antibodies against RIBEYE(B)domain/CtBP2 (conventional imaging). Calcineurin is highly enriched at the synaptic ribbons (arrowheads in $\boldsymbol{A}$ ). $\boldsymbol{B}$, The insets show a single-immunolabeled synaptic ribbon. ONL, 0uter nuclear layer; OPL, outer plexiform layer. Scale bars, $10 \mu \mathrm{m}$.

the Roti-Mark Standard molecular weight markers (T851, Roth), and erythrocyte ghost membranes (Bennett, 1983).

\section{Results}

We first focused on dynamin, a mechano-enzyme that is essential for many forms of endocytosis (Praefcke and McMahon, 2004; Ferguson et al., 2007; Heymann and Hinshaw, 2009; Schmid and Frolov, 2011; Ferguson and De Camilli, 2012). Dynamin has well defined functional domains, including an N-terminal GTPase domain, a central lipid-binding pleckstrin homology domain, a bipartite stalk region, a GTPase effector domain, and a prolinerich C-terminal region to which Src homology 3 (SH3)containing proteins can dock in a differential manner (for review, see Clayton and Cousin, 2009; Ferguson and De Camilli, 2012; Yamashita, 2012). For immunolabeling, we used a well characterized mouse monoclonal antibody against dynamin (Hinshaw and Schmid, 1995; Takei et al., 1995; Warnock et al., 1995) and $0.5 \mu \mathrm{m}$ thin resin sections to obtain optimal resolution. All antibodies used in the present study for immunolabeling analyses detected their respective antigen at the expected running position in Western blot analyses (Fig. $1 A-G$ ).

\section{Dynamin is enriched in the periactive zone of photoreceptor ribbon synapses}

Using the described immunolabeling techniques with $0.5 \mu \mathrm{m}$ thin sections, we found dynamin highly enriched in both synaptic layers of the retina, the OPL and inner plexiform layer (Figs. 2, 3; data not shown). The outer plexiform layer, which contains the photoreceptor ribbon synapses, showed a particularly strong dynamin immunosignal (Figs. 2, 3). High-magnification/ high-resolution analyses demonstrated that this dynamin immunosignal in photoreceptor synapses is present in a discrete manner and is highly enriched around the synaptic ribbon that

$\leftarrow$

(Figure legend continued.) respective immunosignals at the synaptic ribbon $(\boldsymbol{B}, \boldsymbol{D}, \boldsymbol{F}$, and $\boldsymbol{H})$, whereas the control peptide had no influence on the immunosignals $(\boldsymbol{A}, \boldsymbol{C}, \boldsymbol{E}$, and $\boldsymbol{G})$, showing the specificity of the immunolabeling results. ONL, Outer nuclear layer; $\mathrm{OPL}$, outer plexiform layer; INL, inner nuclear layer. Scale bars, $10 \mu \mathrm{m}$. was immunolabeled with antibodies against RIBEYE (Fig. 2A). Similarly, dynamin was found in close proximity to the active zone protein bassoon (data not shown). Bassoon is localized at the base of the synaptic ribbon (tom Dieck et al., 2005). SR-SIM showed a ring of dynamin immunoreactivity closely surrounding the synaptic ribbon (i.e., within $\approx 250 \mathrm{~nm}$ ) (Fig. 2 B, C) (data not shown). The optical resolution obtained by SR-SIM analyses exceeded the resolution that could be obtained by conventional imaging as judged by a comparative imaging analysis of the same incubations either by conventional or SR-SIM imaging at identical magnifications (data not shown). The observation of dynamin being located in close vicinity to the synaptic ribbon was further corroborated with triple-immunolabeling experiments (Fig. $3 A, B$ ). With these triple-immunolabeling experiments, we correlated the localization of dynamin to other proteins of the presynaptic photoreceptor terminal (Fig. $3 A, B$ ). We used antibodies against PSD-95 to label the presynaptic plasma membrane of photoreceptor terminals (Koulen et al., 1998; Aartsen et al., 2009). In contrast to other synapses, PSD-95 is located presynaptically in photoreceptor ribbon synapses, and antibodies against PSD-95 nicely demarcate the outline of the presynaptic terminal (Fig. 3A). Antibodies against VGLUT1 were used to label the glutamatergic synaptic vesicles in the photoreceptor presynaptic terminals (Wojcik et al., 2004) (Fig. 3B). Similar to the previously described immunolabeling data, we observed RIBEYE and dynamin located close to each other at the distal portion of the presynaptic terminal that faces the inner nuclear layer (INL) (Fig. $3 A, B)$. Quantitative analyses of nearest distance measurements indicated that dynamin puncta are located $\approx 125 \pm 50 \mathrm{~nm}$ (mean \pm SD; 100 synapses analyzed) away from RIBEYE puncta and $\approx 120 \pm 40 \mathrm{~nm}$ (100 synapses analyzed) away from the bassoon puncta in retinal sections. Also, isolated mouse photoreceptors, which display the typical ultrastructural morphology of photoreceptor synaptic terminals (data not shown), showed a similar immunolabeling pattern of dynamin. Similar to the observations in the intact retina, a focal enrichment of dynamin was observed in close vicinity to the synaptic ribbon in isolated photoreceptors (data not shown). 

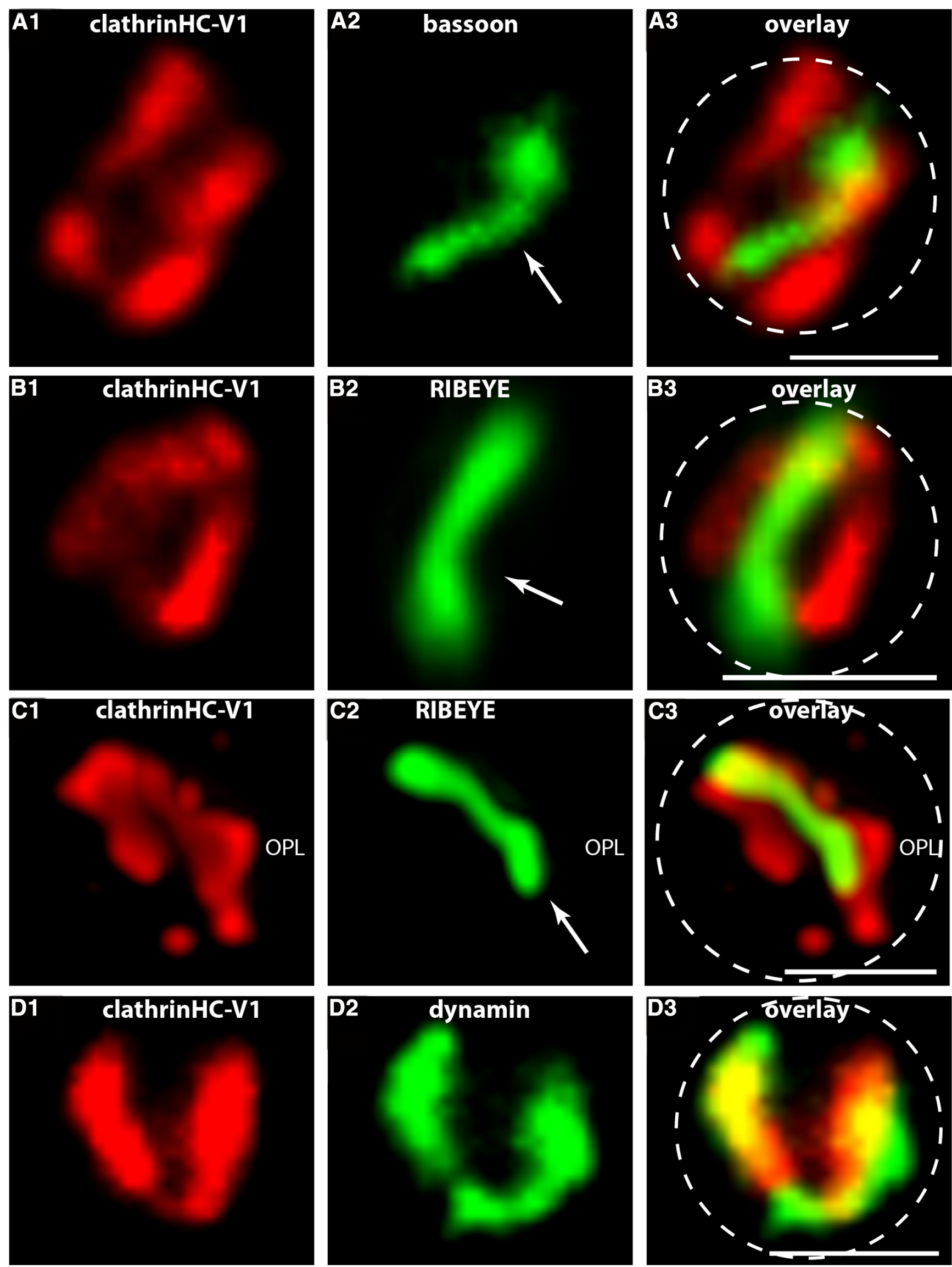

Figure 10. High-magnification analyses of CHC-V1 in relation to bassoon, RIBEYE, and dynamin in single-photoreceptor synapses. $A$, The $0.5 \mu \mathrm{m}$ thin sections of the mouse retina were double immunolabeled with rabbit polyclonal antibodies against CHC-V1 and mouse monoclonal antibodies against bassoon. In $\boldsymbol{B}$ and $\boldsymbol{C}$, sections were double immunolabeled (Figure legend continues.) 

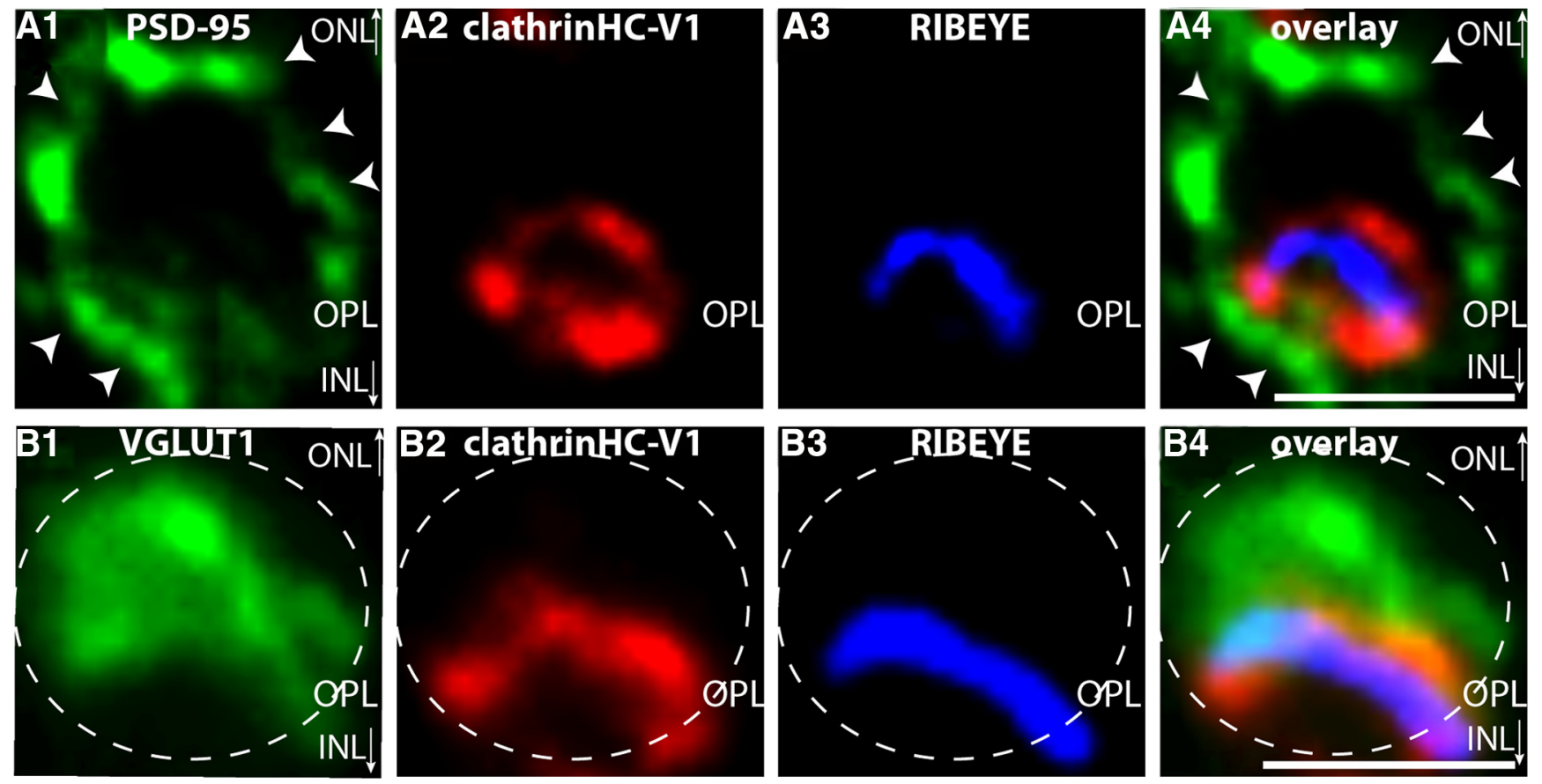

Figure 11. Localization of CHC-V1 in the presynaptic rod photoreceptor terminal in relation to PSD-95 and VGLUT1. $A, B$, The $0.5 \mu \mathrm{m}$ thin sections from mouse retina were triple immunolabeled with mouse monoclonal antibodies against PSD-95 $(\boldsymbol{A})$ or VGLUT1 $(\boldsymbol{B})$, rabbit polyclonal antibodies against CHC-V1 (abcam) $(\boldsymbol{A}, \boldsymbol{B})$ and DyLight 650 direct labeled primary antibodies against RIBEYE(B)/CtBP2 ( $\boldsymbol{A}, \boldsymbol{B})$. The PSD-95 immunosignals in $\boldsymbol{A}$ demarcate the plasma membrane of photoreceptor presynaptic terminals in the OPL ( $\boldsymbol{A}$, arrowheads). In $\boldsymbol{B}$, presynaptic terminals were immunolabeled with antibodies against the vesicular transporter VGLUT1, a marker protein of glutamatergic synaptic vesicles. The dashed circle in $\boldsymbol{B}$ denotes a single-immunolabeled presynaptic photoreceptor terminal. RIBEYE and CHC-V1 are located close to each other at the distal end of the photoreceptor terminal that is facing the INL $(A, B)$. ONL, Outer nuclear layer; clathrinHC-V1, CHC-V1; OPL, outer plexiform layer; INL, inner plexiform layer. Scale bars, $1 \mu \mathrm{m}$.

Finally, we performed postembedding electron microscopy with antibodies against dynamin to determine at the ultrastructural level where exactly dynamin is located in the distal portion of the presynaptic terminal. Postembedding immunogold electron microscopy demonstrated that dynamin is strongly enriched at the presynaptic plasma membrane in close vicinity to the synaptic ribbon (Fig. 4). This area is denoted as the periactive zone in the text because it is located directly lateral to the active zone of exocytosis, where the synaptic ribbons are anchored and exocytosis occurs (for review, see Mercer and Thoreson, 2011; Schmitz et al., 2012). These ultrastructural immunolocalization data support the described light microscopy immunolabeling data, which demonstrated that dynamin is located $\sim 120 \mathrm{~nm}$ distant from the synaptic ribbon. Dynamin was found predominantly, though not exclusively, at the presynaptic plasma membrane in close vicinity to the synaptic ribbon (within $\approx 250 \mathrm{~nm}$ distance from the base of the synaptic ribbon). Some dynamin immunolabeling was also present at the presynaptic plasma membrane, some distance from the ribbon ( $>250 \mathrm{~nm}$ away from the base of the ribbon). There was very little, if any, dynamin at the extrasynaptic outer plasma membrane of the photoreceptor presynaptic terminal,

(Figure legend continued.) with rabbit polyclonal antibodies against CHC-V1 and mouse monoclonal antibodies against RIBEYE(B)-domain/CtBP2. In D, sections were double immunolabeled with rabbit polyclonal antibodies against CHC-V1 and mouse monoclonal antibodies against dynamin. CHC-V1 is located very close to both RIBEYE and bassoon but does not overlap. In contrast, the CHC-V1 immunosignals overlap with the dynamin immunosignal at the active zone of photoreceptor ribbon synapses to a large extent $(\boldsymbol{D}) . \boldsymbol{A}, \boldsymbol{B}$, and $\boldsymbol{D}$ were obtained by conventional imaging at high magnification; $C$ is a maximum projection of a $z$-stack obtained by 2D-SR-SIM. Dashed circles in $\boldsymbol{A}-\boldsymbol{D}$ denote single presynaptic photoreceptor terminals; clathrinHC-V1, CHC-V1; OPL, outer plexiform layer. Scale bars, $1 \mu \mathrm{m}$. which is not in contact with the tips of postsynaptic horizontal and bipolar cells (Fig. 4) (data not shown). The photoreceptor presynaptic terminal has a bell-shaped appearance, which is generated by the invagination of the entire postsynaptic dendritic complex into the photoreceptor presynaptic terminal (for review, see Gray and Pease, 1971; Schmitz, 2009). The outer extrasynaptic plasma membrane of this bell-shaped presynaptic terminal, which is not in contact with the dendritic complex, did not contain any dynamin immunoreactivity (Fig. 4) (data not shown). Only the inner, presynaptic plasma membrane was immunolabeled by the dynamin antibody with a strong enrichment of the dynamin immunogold label in the periactive zones lateral to the synaptic ribbons (Fig. 4A-H) (data not shown).

Major SH3 domain-containing dynamin-binding proteins are also enriched at the periactive zone in photoreceptor synapses Dynamin is typically recruited to membranes via $\mathrm{SH} 3$ domaincontaining proteins such as syndapin/pacsin and amphiphysin (Di Paolo et al., 2002; Yoshida et al., 2004; Wu et al., 2009b; Koch et al., 2011). We localized these proteins in the retina and in photoreceptor ribbon synapses to determine their localization, also compared with localization of dynamin and the synaptic ribbon. We found that the dynamin-interacting proteins amphiphysin and syndapin showed a very similar distribution as dynamin (Fig. 5). Both amphiphysin and syndapin were highly enriched in the synaptic layers of the retina, particularly in the OPL, and showed a highly discrete, punctate distribution pattern at these sites (Fig. 5). Amphiphysin and syndapin were particularly enriched in close proximity to the synaptic ribbon that was visualized with antibodies against RIBEYE (Fig. $5 A, B$ ).

Amphiphysin and syndapin were also highly clustered around the synaptic ribbon in these double-immunolabeling experi- 

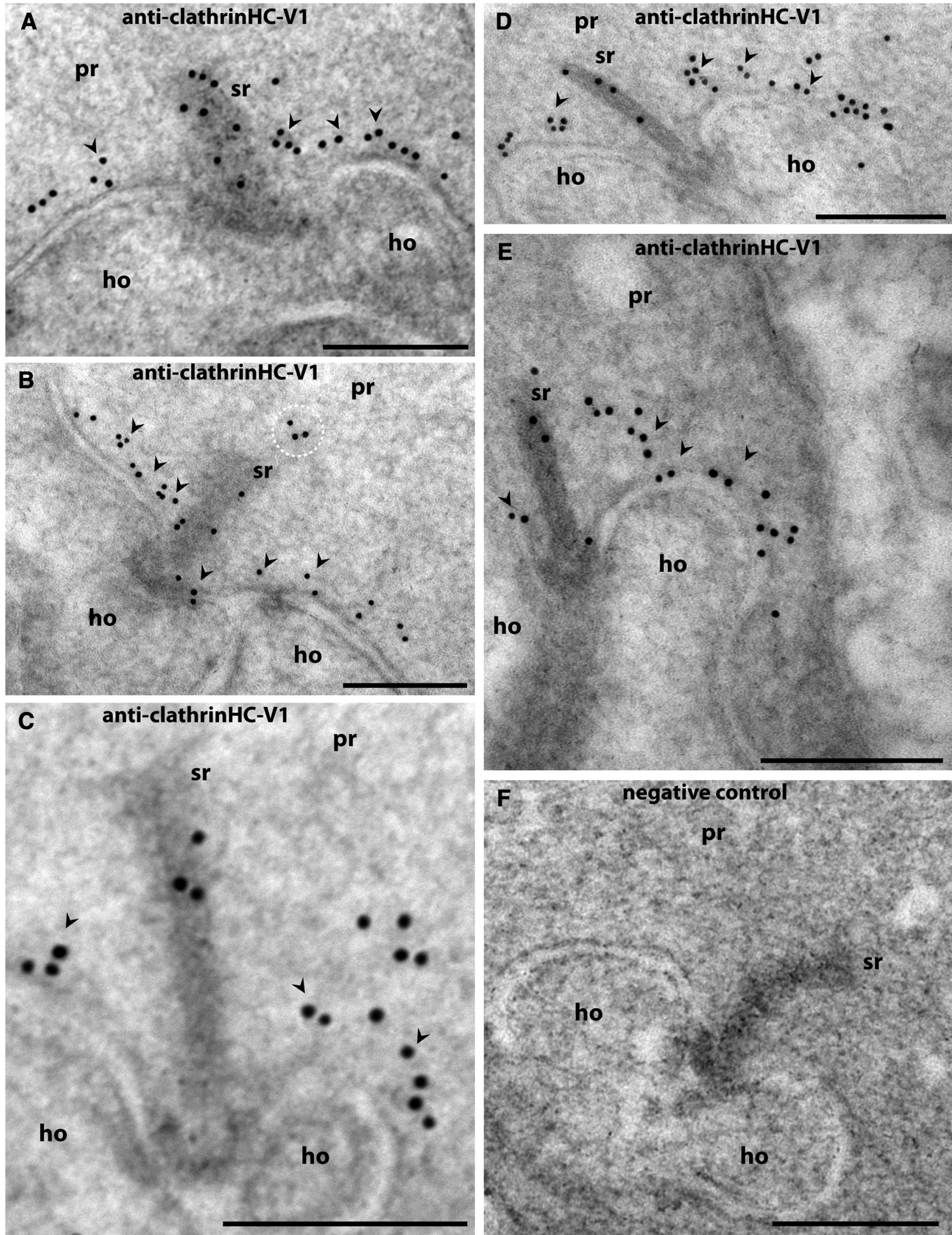

Figure 12. Postembedding immunogold labeling of photoreceptor synapses from the mouse retina with antibodies against CHC-V1. A-E, Ultrathin sections of the mouse retina were immunolabeled with mouse monoclonal antibodies against CHC-V1 (catalog \#21679, abcam). Binding of the primary antibodies was detected with goat anti-rabbit antibodies conjugated to $10 \mathrm{~nm}$ gold particles. A strong CHC-V1 immunogold label (arrowheads) was observed at the plasma membrane in close proximity to the synaptic ribbon (sr). The immunogold labeling (Figure legend continues.) 
ments in 2D-SR-SIM analyses (data not shown). The antibodies against amphiphysin/syndapin did not work for postembedding immunogold labeling in our hands. Therefore, we applied triple immunolabeling SR-SIM analyses to define the localization of these proteins in the presynaptic terminal as precise as possible at the light microscopic level. Using 2D-SR-SIM, we found that both amphiphysin as well as syndapin are typically localized and strongly enriched around the synaptic ribbon in these tripleimmunolabeling analyses (Fig. 5C,D). The impression was confirmed by using 3D-SR-SIM of these triple-immunolabeling experiments (Fig. 6A,B). Both 2D-SR-SIM and 3D-SR-SIM results showed a tubulo-/vesicular-like distribution pattern of syndapin and amphiphysin around the synaptic ribbon (Figs. 5C,D, $6 A, B)$.

Endophilin is another SH3-containing protein that can interact with dynamin (Mizuno et al., 2010; Llobet et al., 2011; Milosevic et al., 2011). In contrast to amphiphysin and syndapin (Figs. $5,6)$, endophilin was neither enriched around the synaptic ribbon (Fig. 7A) nor restricted to the dynamin immunosignal around the synaptic ribbon (Fig. $7 B$ ). Endophilin was diffusely distributed throughout the entire presynaptic terminal (Fig. 7A$E)$. In these experiments, the extension of the presynaptic terminal was immunolabeled with panSV2 (Fig. $7 C, D$ ) or with antibodies against the VGLUT1 (Fig. 7E), both with identical results. All the described immunolabeling experiments could be specifically blocked with the respective antigen used for immunization (Fig. 8) (data not shown) but not with irrelevant peptides demonstrating the specificity of the immunolabeling analyses.

\section{Localization of calcineurin, a putative $\mathrm{Ca}^{2+}$ sensor of endocytosis, in photoreceptor ribbon synapses}

Interestingly, calcineurin, a $\mathrm{Ca}^{2+}$-sensing phosphatase involved in coupling $\mathrm{Ca}^{2+}$-dependent activity and endocytosis (for review, see Clayton and Cousin, 2009), is highly enriched at the synaptic ribbon complex (Fig. 9). Thus, the influx of $\mathrm{Ca}^{2+}$ through voltage-gated calcium channels could mediate activitydependent endocytosis at the synaptic ribbon through such a mechanism (see Discussion).

\section{Evidence for two distinct clathrin heavy chain variants (CHC-V1 and CHC-V2) in the presynaptic photoreceptor terminal at distinct localizations}

Finally, we analyzed for the distribution of clathrin. Clathrin is instrumental for many, though not all, forms of synaptic vesicle endocytosis (for review, see Murthy and de Camilli, 2003; Wilbur et al., 2005; Doherty and McMahon, 2009; Brodsky, 2012). To analyze the distribution of clathrin in photoreceptor presynaptic terminals, we used four different antibodies against different epitopes of clathrin heavy chain. In humans, two clathrin heavy chain genes ( $\mathrm{CHC} 17$ and $\mathrm{CHC} 22)$ are present (for review, see Brodsky, 2012). In the mouse genome, there is only one active clathrin heavy gene that corresponds to human $\mathrm{CHC} 17$. A second clathrin gene is a nonactive pseudogene in the mouse genome (Wakeham et al., 2005; for review, see Brodsky, 2012).

\section{$\leftarrow$}

(Figure legend continued.) experiments confirm the previously shown immunofluorescence labeling data and demonstrate the enrichment of $\mathrm{CHC}-\mathrm{V} 1$ in the periactive zone of the photoreceptor ribbon synapse. Arrowheads indicate the $\mathrm{CHC}-\mathrm{V} 1$ enrichment in the periactive zone. Only a very minor fraction of $\mathrm{CHC}-\mathrm{V} 1$ was found in the presynaptic cytosol (dashed circle). $\boldsymbol{F}$ is a negative control in which the primary antibody was omitted. clathrinHC-V1, CHC-V1; pr, presynaptic photoreceptor terminal; ho, dendritic tips of postsynaptic horizontal cells; pm, plasma membrane. Scale bars: $\boldsymbol{A}-\boldsymbol{F}, 250 \mathrm{~nm}$.
We used two different antibodies raised against the $\mathrm{C}$ terminus of clathrin heavy chain (ab21679, abcam; P1663, Cell Signaling Technology) for the immunolocalization analyses. The clathrin variant, detected by these antibodies, is denoted as $\mathrm{CHC}-\mathrm{V} 1$ in the following text. Using these antibodies against CHC-V1, we observed a strong clathrin signal in close vicinity to the RIBEYE-immunolabeled synaptic ribbon (Figs. 10, 11) (data not shown). The clathrin immunosignal was surrounding both the bassoon-labeled active zone (Fig. 10A) and the RIBEYEimmunolabeled synaptic ribbon (Fig. 10B). Also, SR-SIM analyses of thin-sectioned mouse photoreceptor synapses that were double immunolabeled with antibodies against RIBEYE and CHC-V1 demonstrated a close spatial correlation of these proteins. The $\mathrm{CHC}-\mathrm{V} 1$ immunosignal closely surrounded the RIBEYE-labeled synaptic ribbon in these SR-SIM analyses (Fig. 10C). The CHC-V1 immunosignal overlapped to a large extent with the dynamin immunosignal (Fig. 10D).

The CHC-V1 immunosignal is, similar to the synaptic ribbon, localized in the distal portion of the synaptic terminal that faces the INL (Fig. 11). The borders of the presynaptic terminal were marked either with antibodies against PSD-95, which labels the presynaptic plasma membrane of photoreceptor terminals (Fig. $11 A$ ), or with antibodies against VGLUT1 (Fig. 11B), a component of the presynaptic glutamatergic vesicles. In Western blotting analyses, CHC-V1 migrated at the expected molecular weight position of clathrin heavy chain (Fig. 1F; see also Fig. 13A, lane 1). The CHC-V1 immunofluorescence signals could be blocked by preabsorption with the respective peptide used for immunization (see Fig. 13C) but not by preabsorption with control peptides (see Fig. 13B), demonstrating the specificity of the immunolabeling data.

Finally, postembedding immunogold electron microscopy with antibodies against $\mathrm{CHC}-\mathrm{V} 1$ demonstrated that a strong CHC-V1 immunosignal was actually found at the presynaptic plasma membrane in close proximity (within $\approx 250 \mathrm{~nm}$ ) from the synaptic ribbon (Fig. 12). These ultrastructural data completely confirm and extend the light microscopic CHC-V1 immunolabeling data and show the localization of CHC-V1 in the periactive zone (Fig. 12) in a very similar position as that shown above for dynamin (Fig. 4).

We found evidence for a second clathrin-containing compartment that is not spatially related to the synaptic ribbon (see Figs. 14, 15). This clathrin-containing compartment was labeled by two different antibodies directed against epitopes in the central region of clathrin heavy chain (ab59710, Abcam; $\mathrm{X} 22$, abcam). This clathrin heavy chain variant detected by these latter antibodies is denoted as CHC-V2 in the following text. CHC-V2 migrates slightly slower than CHC-V1 at a slightly higher molecular weight position (Fig. 13A). This becomes obvious if low percentage (5\%) acrylamide SDS-PAGE gels (Fig. 13A) were used (instead of $8 \%$ acrylamide running gels; Fig. $1 G$ ). In immunolabeling analyses, $\mathrm{CHC}-\mathrm{V} 2$ is located a large distance from both RIBEYE and the active zone protein bassoon as well as $\mathrm{CHC}-\mathrm{V} 1$ as judged by high-resolution double-immunolabeling analyses (Fig. 14A-C). The mean distance of CHC-V2 from RIBEYE and bassoon puncta (nearest, mean distance) is $\approx 580 \pm 210 \mathrm{~nm}$ ( 100 synapses analyzed) for CHC-V2-RIBEYE and $\approx 750 \pm 200 \mathrm{~nm}$ (100 synapses analyzed) for CHC-V2-bassoon. These are two large distances particularly if one considers that the diameter of a single rod photoreceptor terminal, measured as distance of the lateral PSD-95 immunosignals of a single synaptic terminal, is $\approx 1280 \pm 330 \mathrm{~nm}$ (100 synapses analyzed). Despite the large 
A

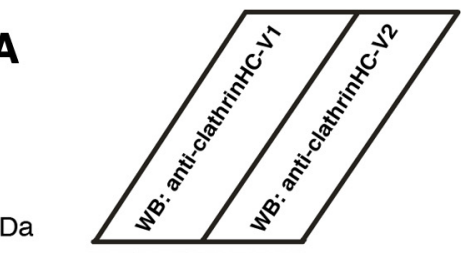

$240=$

200

170

$\longleftarrow$ clathrinHC-V2

$130=$

100
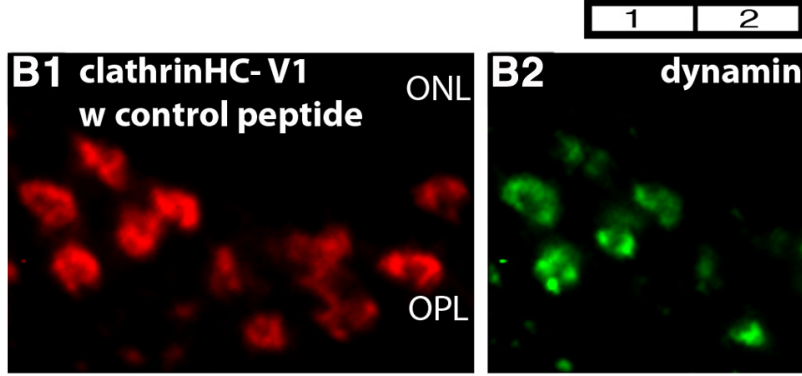

C1 clathrinHC- V1 w blocking peptide

OPL
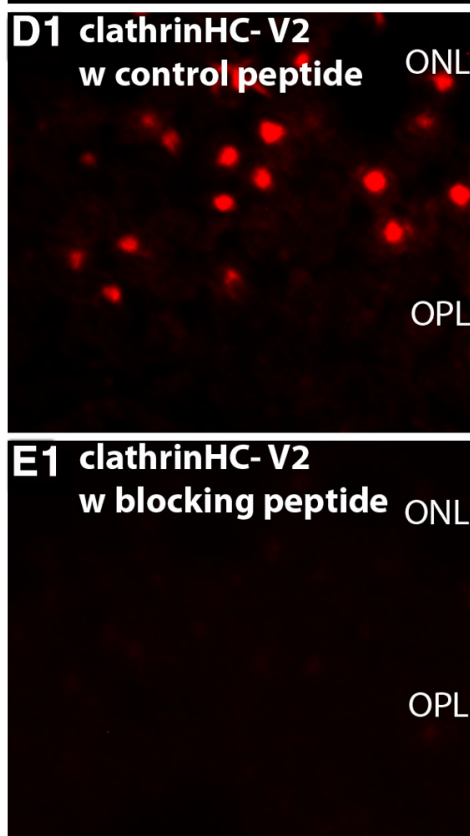

dynamin
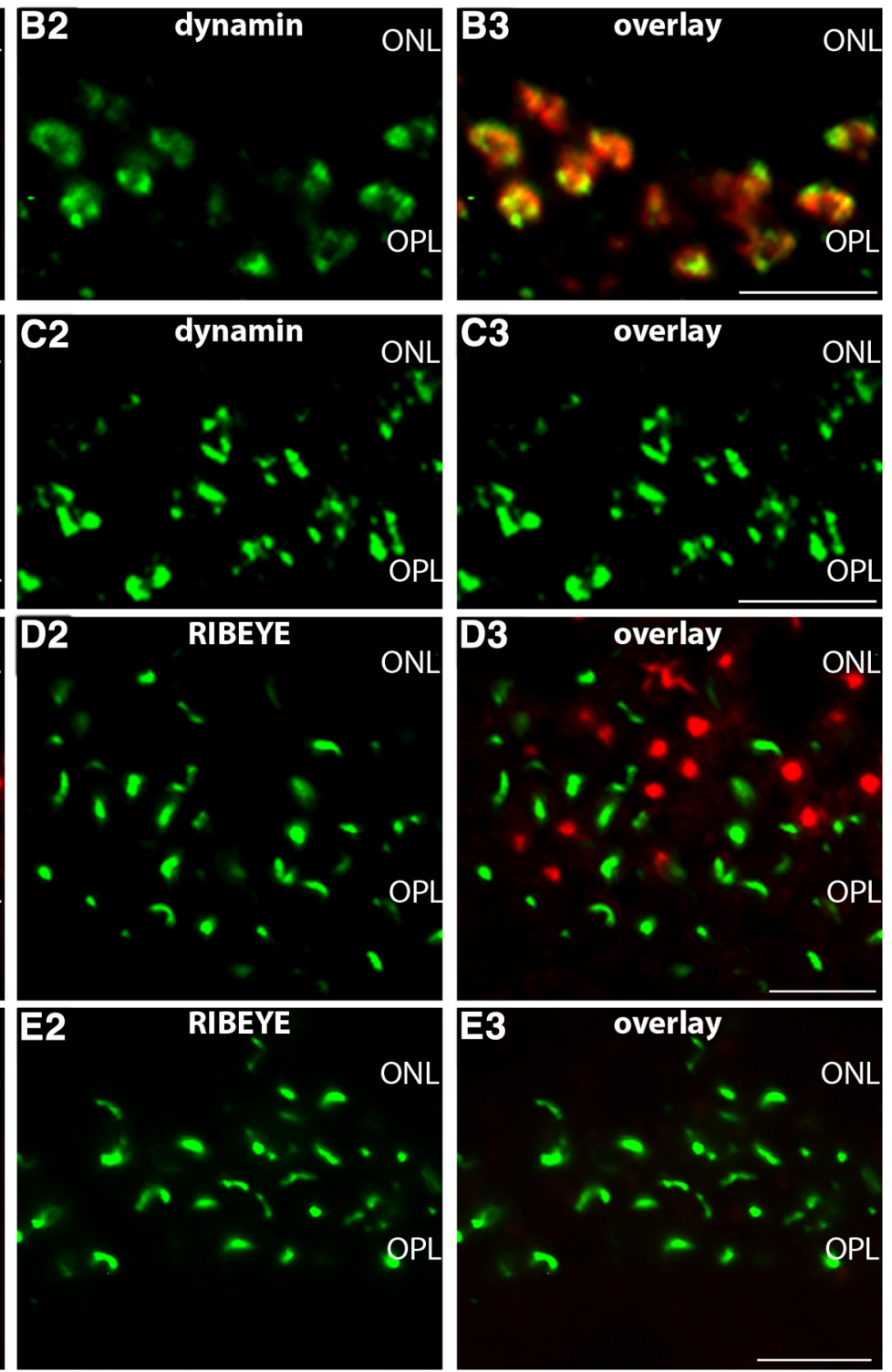

Figure 13. A, Western blot analyses of two different clathrin heavy chains, variant 1 and variant 2 (after separation in 5\% acrylamide SDS-PAGE running gels). The running position of the immunoreactive bands detected by the different antibodies against the CHC-V1 (lane 1) and antibodies against clathrin heavy chain variant 2 (lane 2) differ slightly. CHC-V1 is slightly smaller than CHC-V2 in Western blot analyses (after separation in 5\% acrylamide SDS-PAGE running gels). $\boldsymbol{B}-\boldsymbol{E}$, Pre-absorption control experiments for the antibodies against CHC-V1 (Figure legend continues.) 
distance of CHC-V2 from the synaptic ribbon, $\mathrm{CHC}-\mathrm{V} 2$ is still located in the presynaptic terminal as judged by tripleimmunolabeling experiments with antibodies against PSD-95/VGLUT1, RIBEYE, and anti-CHC-V2 (Fig. 15A,B). But, in contrast to $\mathrm{CHC}-\mathrm{V} 1, \mathrm{CHC}-\mathrm{V} 2$ is located in the proximal portion of the presynaptic terminal, which is separated from the synaptic ribbon by the bulk of glutamatergic synaptic vesicles (Fig. 15B). The antibodies against CHC-V2 did not work in postembedding immunogold electron microscopy. But since this clathrin variant is clearly not associated with the synaptic ribbon complex the identification of the underlying organelle, though principally important, is of minor relevance for the present study, which is concerned with vesicle retrieval in the periactive zone surrounding the synaptic ribbon complex (see also Discussion).

\section{The periactive zone of photoreceptor} ribbon synapses is a hotspot of endocytic activity

Finally, we also presented functional evidence that the synaptic ribbon complex is a hotspot of endocytic activity. If isolated mouse photoreceptors (Fig. 16A) were loaded with a short pulse of the fluid-phase marker SR101, SR101 was predominantly taken up in immediate vicinity to the synaptic ribbon (Fig. 16B-D) (data not shown). The synaptic ribbon was visualized by immunolabeling with antibodies against RIBEYE in these experiments. The uptake of SR101 was dependent upon dynamin activity because SR101 uptake was completely blocked in the presence of dynasore, a specific inhibitor of dynamin activity (Fig. 16E) (data not shown). Our data are schematically summarized in Figure 17.

\section{Discussion}

In the present study, we analyzed the distribution of major proteins of the endocytic machinery in photoreceptor synapses with immunolabeling and high-resolution imaging. We found a strong enrichment of these proteins in the periactive zone (i.e., the area that surrounds the active zone and the synaptic ribbon). In agreement with the periactive zone enrichment, we observed a preferential uptake of sulforhodamine (SR101), a fluid-phase endocytosis marker, around synaptic

$\overline{\text { (Figure legend continued.) and CHC-V2 (immunolabeling analyses). Double immunolabeling }}$ of $0.5 \mu \mathrm{m}$ thin mouse retinal sections with the indicated antibodies preabsorbed with either their specific peptide used for immunization $(\boldsymbol{C}, \boldsymbol{E})$ or with an unrelated control peptide $(\boldsymbol{B}, \boldsymbol{D})$. In parallel, sections were incubated with monoclonal anti-dynamin antibodies $(\boldsymbol{B}, \boldsymbol{C})$ or RIBEYE $(\boldsymbol{D}$, $E$ ) as labeling positive controls. The specific peptides completely blocked the respective clathrin heavy chain immunosignals $(\boldsymbol{C}, \boldsymbol{E})$, whereas the control peptide had no influence of the clathrin heavy chain immunosignals $(\boldsymbol{B}, \boldsymbol{D})$ showing the specificity of the immunolabeling signals. $0 \mathrm{NL}$, Outer nuclear layer; OPL, outer plexiform layer; clathrinHC-V1, CHC-V1; clathrinHC-V2, CHC-V2. Scale bars: $\boldsymbol{B}-\boldsymbol{E}, 5 \mu \mathrm{m}$.
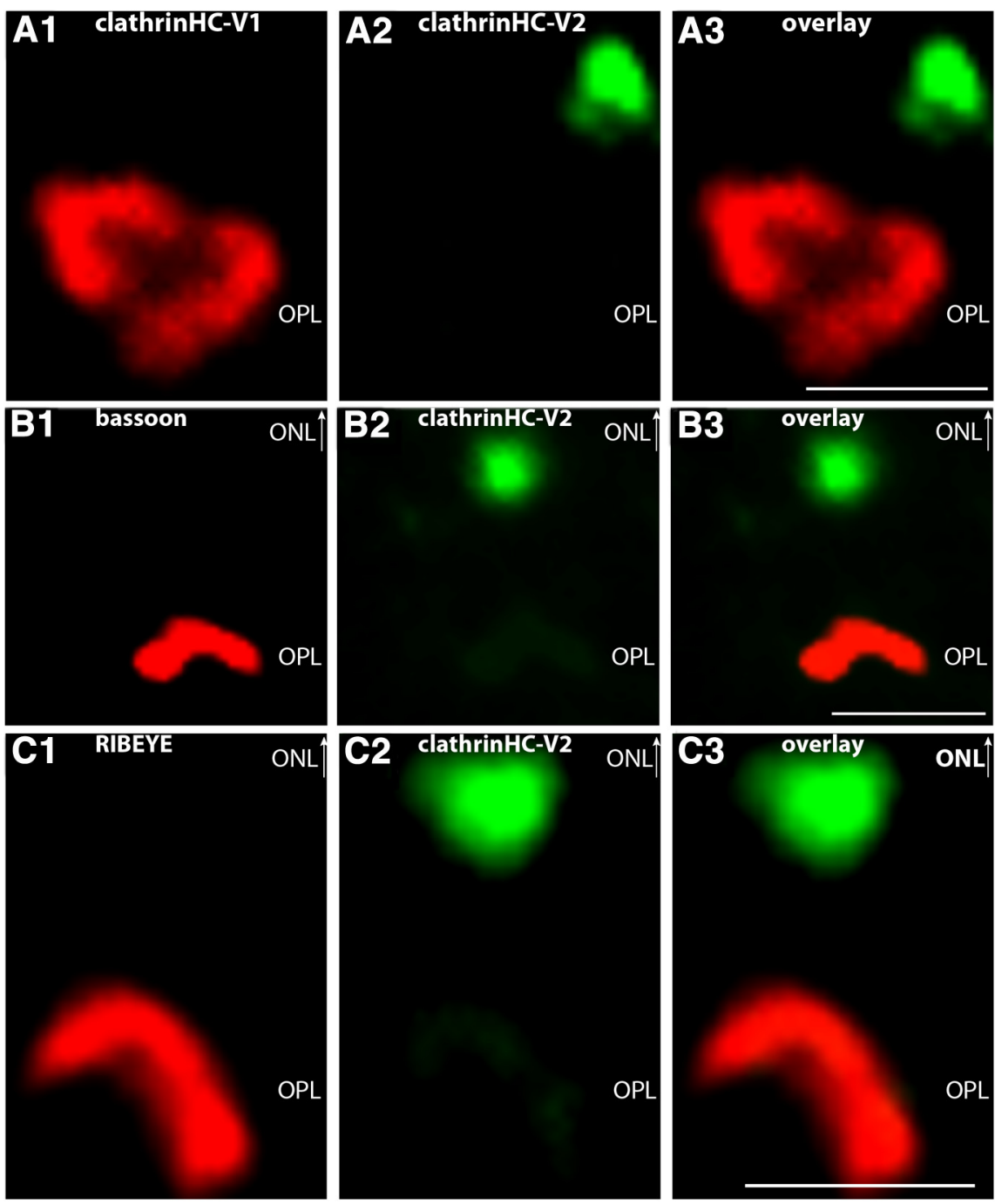

Figure 14. Two different clathrin heavy chain variants are found in photoreceptor terminals at different locations (immunofluorescence analyses). $\boldsymbol{A}$, The $0.5 \mu \mathrm{m}$ thin sections of the mouse retina were double immunolabeled with rabbit polyclonal antibodies against $\mathrm{CHC}-\mathrm{V} 1$ and mouse monoclonal antibodies against CHC-V2. The immunosignals for the two variants of clathrin heavy chain do not overlap and are located a large distance from each other $(\boldsymbol{A})$. In $\boldsymbol{B}$ and $\boldsymbol{C}$, sections were double immunolabeled proteins in the presynaptic photoreceptor terminal. Bassoon and RIBEYE are localized in a large distance from immunolabeled CHC-V2. For further localization data of CHC-V2 in relation to other proteins of the presynaptic terminal, see also Figure 15. ONL, Outer nuclear layer; OPL, outer plexiform layer; clathrinHC-V1, CHC-V1; clathrinHC-V2, CHC-V2. Scale bars, $1 \mu \mathrm{m}$.

ribbons in mouse photoreceptors. These data suggest that the periactive zone region in photoreceptor synapses is a hotspot of endocytic vesicle retrieval. Dynamin is likely to play an essential role in periactive zone endocytosis because dynasore, a specific inhibitor of dynamin activity, completely inhibited ribbon complex-associated uptake of SR101. Visualization of periactive zone endocytosis in photoreceptor terminals was achieved by short loading pulses with sulforhodamine (SR101) as an uptake marker for endocytosis. Longer tracer loading times generate a diffuse presynaptic labeling pattern (data not shown) similar to HRP uptake experiments in previous EM studies (Ripps et al., 1976; Schacher et al., 1976; Schaeffer and Raviola, 1978; Cooper and McLaughlin, 1983).

The periactive zone vesicle retrieval could promote rapid synaptic vesicle recycling, which is particularly important for the tonically active ribbon synapses. The suggested vesicle retrieval at the periactive zone close to the synaptic ribbon is in line with recent findings that supported a major role of synaptic ribbons 

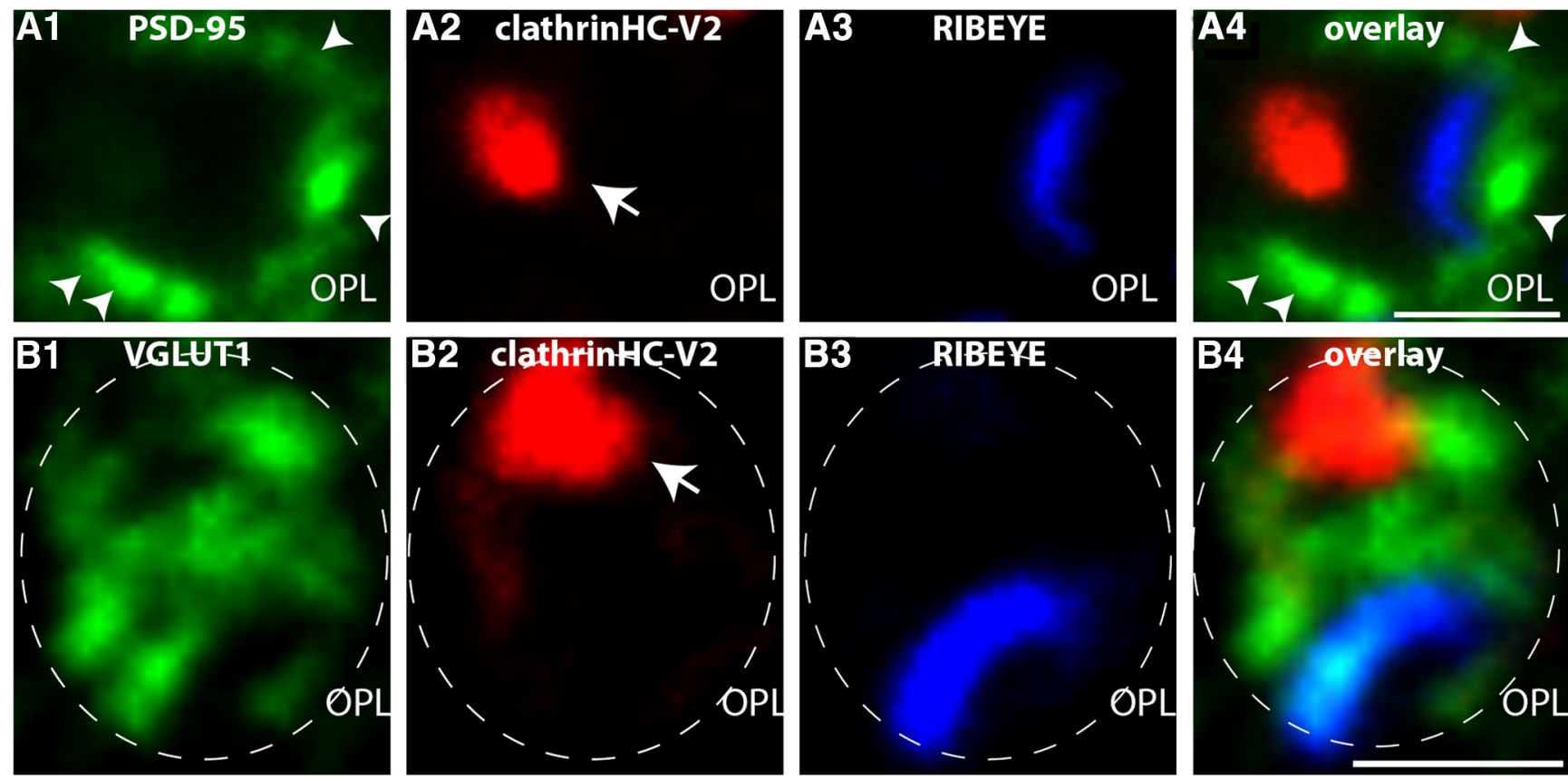

Figure 15. Localization of CHC-V2 (clathrinHC-V2) in the presynaptic photoreceptor terminal in relation to PSD-95 and VGLUT1. In $A$ and $B, 0.5 \mu \mathrm{m}$ thin sections of the mouse retina were triple immunolabeled with rabbit polyclonal antibodies against CHC-V2 and mouse monoclonal antibodies against either PSD-95 (A) or VGLUT1 (B). The synaptic ribbon was visualized with a DyLight 650-labeled primary antibody against RIBEYE(B)-domain/CtBP2. The PSD-95 immunosignals demarcate the plasma membrane of the entire photoreceptor presynaptic terminal (arrowheads). The CHC-V2 antibody labeled a spot-like structure in the presynaptic terminal (arrows) that—in contrast to CHC-V1—was localized in a large distance from the synaptic ribbon. A virtually identical immunolabeling pattern was obtained if the sections were triple immunolabeled with a monoclonal antibody (X22, abcam) against CHC-V2, a rabbit polyclonal antibody against PSD-95, and the DyLight 650 directly labeled antibody against RIBEYE(B)-domain/CtBP2 (data not shown). Identical results were obtained if presynaptic vesicles were immunolabeled with rabbit polyclonal antibodies against VGLUT1 and if CHC-V2 was immunolabeled with the monoclonal clathrin heavy chain antibody X22 (abcam) (data not shown). Similarly, as in $\boldsymbol{A}$ and $\boldsymbol{B}$, the localization of the synaptic ribbon was determined by DyLight 650-labeled primary antibody against RIBEYE(B)-domain/CtBP2 in these incubations (data not shown). B, The CHC-V2 was located in a spot-like manner (arrow in B2) at the entry of the presynaptic terminal. CHC-V2 was separated from the synaptic ribbon by the bulk of glutamatergic synaptic vesicles that were immunolabeled by VGLUT1 antibodies (B). This distribution of CHC-V2 is in contrast to the distribution of CHC-V1 (see Figs. 10, 11). In contrast to CHC-V2, CHC-V1 is highly enriched around the synaptic ribbon (compare with Fig. 11A,B). Dashed circles in $\boldsymbol{B}$ denote a single presynaptic photoreceptor terminal in the outer plexiform layer (OPL). clathrinHC-V2, CHC-V2; clathrinHC-V1, CHC-V1. Scale bars, $1 \mu \mathrm{m}$.

for recycling of release-ready synaptic vesicles (Jackman et al., 2009; Babai et al., 2010). This proposal is conceptionally similar to periactive zone endocytosis found also in other synapses (e.g., in lamprey neurons, neuromuscular junction and hippocampal synapses) (Teng et al., 1999; for review, see Shupliakov, 2009; Haucke et al., 2011; Hua et al., 2011; Saheki and De Camilli, 2012; Yamashita, 2012). It will be interesting to see how regulation of periactive zone endocytosis is accomplished in these physiologically different types of synapses.

In general, different forms of endocytosis involve different sets of proteins (for review, see Wu et al., 2007; Dittman and Ryan, 2009; Doherty and McMahon, 2009; Donaldson et al., 2009; Scita and Di Fiori, 2010; Sandvig et al., 2011; Saheki and De Camilli, 2012). We found dynamin as well as the dynaminassociated proteins syndapin/pacsin and amphiphysin highly enriched in close vicinity to the synaptic ribbons. In agreement with the light microscopic immunolabeling data, dynamin was found preferentially localized at the presynaptic plasma membrane next to the synaptic ribbon, as judged by postembedding immunogold electron microscopy. These ultrastructural data further support the concept of periactive zone endocytosis in ribbon synapses. Dynamin immunoreactivity at the plasma membrane outside of the periactive zone could support retrieval of vesicles that have been fused outside of the ribbon-associated active zone (Midorikawa et al., 2007; Zenisek, 2008). Endophilin was also found at the synaptic ribbon but predominantly diffusely distributed throughout the entire presynaptic terminal. In conventional synapses, endophilin is also distributed diffusely in the entire synaptic vesicle pool, although endophilin acts at the plasma membrane (Bai et al., 2010). Similarly, intersectin, a periactive zone component in conventional synapses, cycles between different locations in the presynaptic terminal (for review, see Shupliakov, 2009; Pechstein et al., 2010; Haucke et al., 2011).

Remarkably, we detected two immunologically distinct forms of clathrin heavy chain in the presynaptic photoreceptor terminal, CHC-V1 and CHC-V2. CHC-V1 was associated with the synaptic ribbon complex, whereas $\mathrm{CHC}-\mathrm{V} 2$ was not localized at synaptic ribbons. $\mathrm{CHC}-\mathrm{V} 1$ immunosignals at the synaptic ribbon complex largely overlapped with the dynamin immunoreactivity at that site. In support of these light microscopic data, we showed by immunogold electron microscopy that $\mathrm{CHC}-\mathrm{V} 1$ is preferentially localized at the presynaptic plasma membrane in close vicinity to the active zone and synaptic ribbon. The antibodies against $\mathrm{CHC}-\mathrm{V} 2$ did not work for postembedding immunogold electron microscopy. But the $\mathrm{CHC}-\mathrm{V} 2$ immunosignals were clearly localized a large distance $(\approx 580 \mathrm{~nm})$ from the bassoonlabeled active zone in the proximal part of the presynaptic terminal and thus cannot contribute to periactive zone endocytosis. The identity and function of this $\mathrm{CHC}-\mathrm{V} 2$-containing compartment needs to be elucidated in detail by future investigations. The molecular difference between $\mathrm{CHC}-\mathrm{V} 1$ and $\mathrm{CHC}-\mathrm{V} 2$ is unknown, but could involve differential splicing and/or differential post-translational modifications.

Our proposal of periactive zone endocytosis in photoreceptor synapses is in agreement with electron microscopic data that demonstrated coated buds and coated vesicles at the presynaptic 

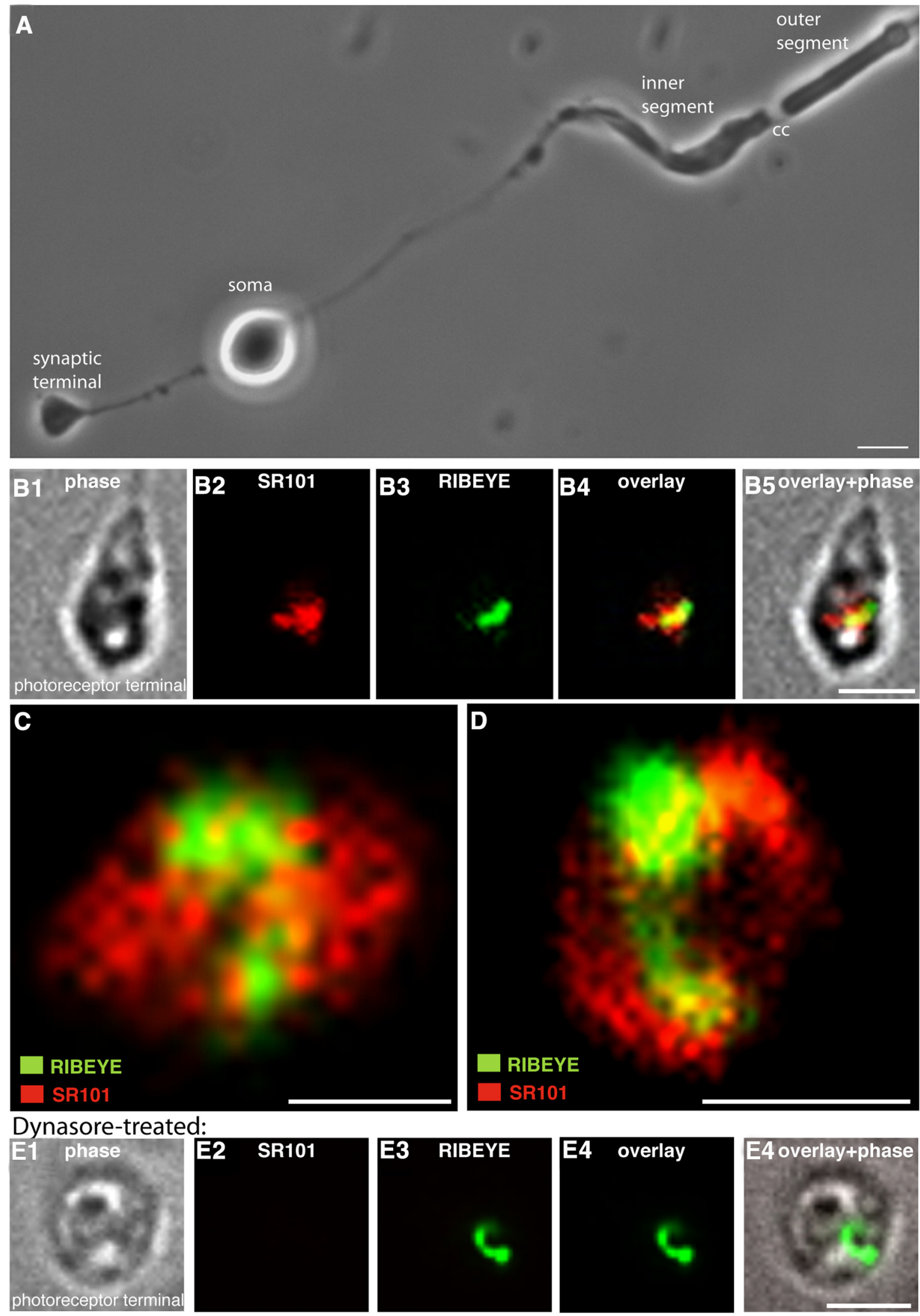

Figure 16. Imaging of synapticribbon-associated endocytosis in isolated mouse photoreceptors. Isolated mouse photoreceptors (shown in A) were incubated for 2 min with sulforhodamine (SR101), which is taken up by fluid-phase endocytosis. Afterward, SR101-loaded photoreceptors were fixed and immnunolabeled with antibodies against RIBEYE(B)-domain/CtBP2. A hotspot of SR101 uptake is found in close association with the synaptic ribbon ( $\boldsymbol{B}-\boldsymbol{D}$; and data not shown). $\boldsymbol{B}$ was obtained by conventional imaging; $(\boldsymbol{C}$ and $\boldsymbol{D}$ are maximum projections of $z$-stacks from confocal imaging. Pretreatment with dynasore, a specific inhibitor of dynamin (100 $\mu \mathrm{m}$ ), completely inhibited the synaptic ribbon-associated uptake of SR101 (red channel) (E and data not shown). Scale bars, $1 \mu \mathrm{m}$. 


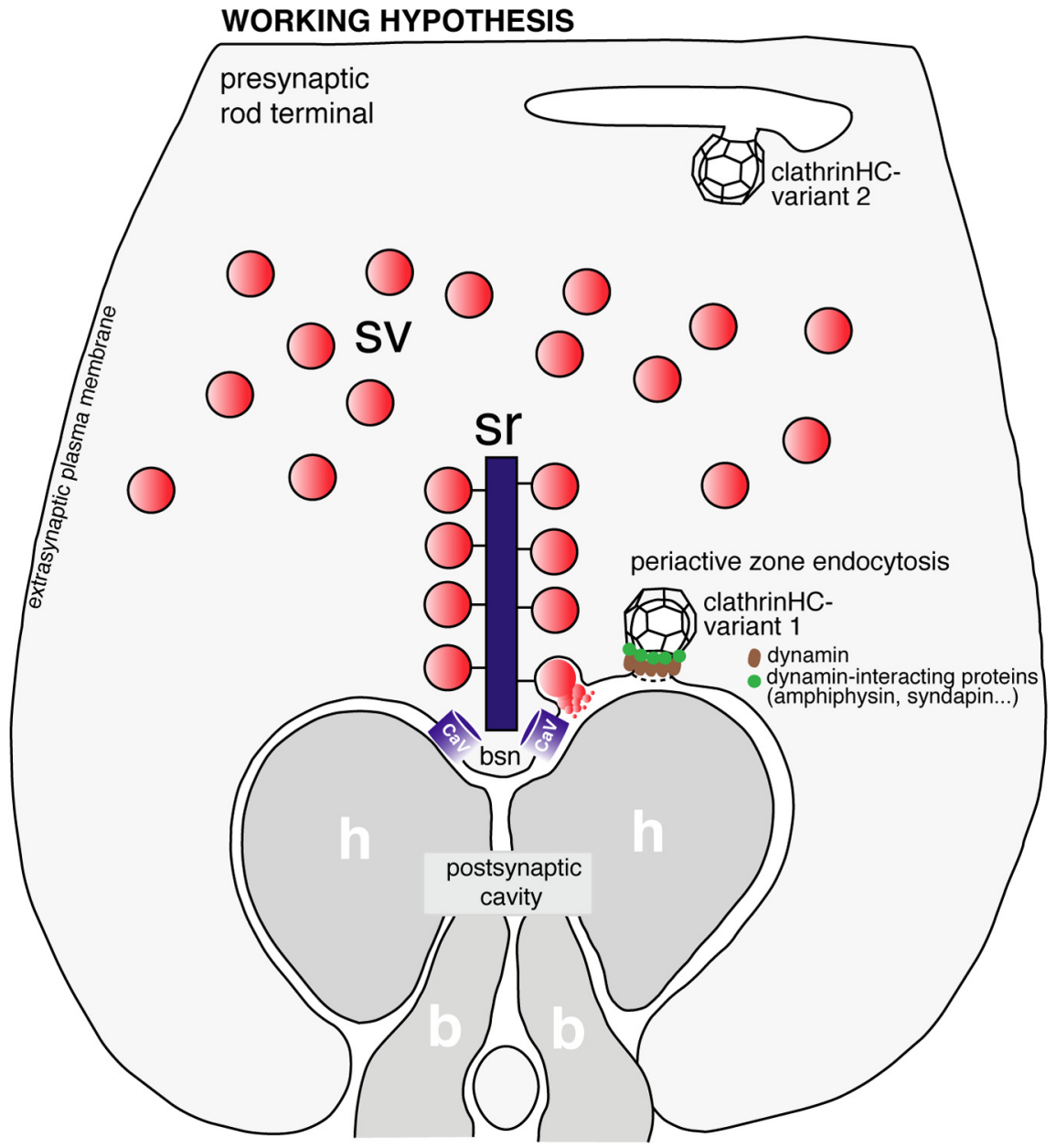

Figure 17. Simplified, schematic summary of the immunolocalization data presented in the manuscript. Key players of endocytic membrane traffic, including dynamin, dynamin-binding proteins, and $\mathrm{CHC}-\mathrm{V} 1$, are enriched in a periactive zone of photoreceptor synapses. Besides CHC-V1, CHC-V2 is also present in the presynaptic photoreceptor terminal. In contrast to CHC-V1, CHC-V2 is located a large distance from the periactive zone, possibly on an endosomal compartment in the proximal region of the presynaptic terminal. Endosomal-like membrane compartments have been previously observed by transmission electron microscopy in this part of the photoreceptor terminal (Ripps et al., 1976; Schacher et al., 1976; Schaeffer and Raviola, 1978; Cooper and McLaughlin, 1983). The drawing of the photoreceptor terminal is modified based on a drawing of Gray and Pease (1971). sr, Synaptic ribbon; sv, synaptic vesicles; clathrinHC-V1, clathrin heavy chain variant 1, CHC-V1; clathrinHC-V2, CHC-V2; CaV, voltage-gated calcium channels of the photoreceptor active zone; $h$, postsynaptic dendritic tip of a horizontal cell; $b$, postsynaptic dendritic tip of an invaginating bipolar cell; bsn, bassoon.

plasma membrane lateral to the synaptic ribbon (Gray and Pease, 1971). These coated membranes were located in pouches of the presynaptic terminals located lateral to the synaptic ribbon and opposite to the dendritic tips of horizontal cells. These are exactly the sites where we found a strong enrichment of dynamin and a clathrin heavy chain variant (CHC-V1) using immunogold electron microscopy.

Previous analyses, mostly obtained from electrophysiological analyses of retinal bipolar cells and inner ear hair cells, revealed at least two distinct modes of endocytosis in ribbon synapses: a fast phase and a slow phase of endocytosis (Neves and Lagnado, 1999; Moser and Beutner, 2000; Beutner et al., 2001; Wu et al., 2007; for review, see LoGiudice and Matthews, 2007; Smith et al., 2008; Royle and Lagnado, 2010), with time constants of $\approx 1$ and $\approx 15-30$ s. Future analyses need to show to which mode periactive endocytosis will contribute. In terms of its localization, it would be ideally suited to serve fast endocytosis in photoreceptors. In retinal bipolar cells, fast endocytosis was found to be clathrin independent however (Jockusch et al., 2005).
The local periactive zone endocytic machinery in photoreceptor synapses will be exposed to fluctuations of presynaptic $\left[\mathrm{Ca}^{2+}\right]_{\mathrm{i}}$ that result from $\mathrm{Ca}^{2+}$ influx through voltage-gated $\mathrm{Ca}^{2+}$ channels at the active zone. The role of $\mathrm{Ca}^{2+}$ in endocytosis is not completely understood (for review, see Smith et al., 2008; Shupliakov, 2009; Yamashita, 2012). But many recent studies have demonstrated that increases of $\left[\mathrm{Ca}^{2+}\right]_{\mathrm{i}}$ can promote and activate endocytosis (Neves and Lagnado, 1999; Beutner et al., 2001; Neves et al., 2001; Wu et al., 2005, 2007, 2009a; Hosoi et al., 2009; Babai et al., 2010; Schnee et al., 2011). Recent analyses suggested that vesicle recycling occurs close to presynaptic voltage-gated $\mathrm{Ca}^{2+}$ channels in photoreceptor ribbon synapses and could be stimulated by increases of presynaptic $\mathrm{Ca}^{2+}$ (Babai et al., 2010).

We found calcineurin, a $\mathrm{Ca}^{2+}$. activated calmodulin-dependent phosphatase, localized in close vicinity to the synaptic ribbon. In conventional synapses, calcineurin is a $\mathrm{Ca}^{2+}$-dependent regulator of endocytosis that adjusts activity-dependent endocytosis by dephosphorylating endocytic proteins (e.g., dynamin). By this way, it controls functionally important protein-protein interactions in endocytic networks (for review, see Cousin and Robinson, 2001; Clayton and Cousin, 2009; Yamashita, 2012). Thus, calcineurin is a potential $\mathrm{Ca}^{2+}$ sensor that could adjust local, ribbonassociated endocytosis to different levels of synaptic activity also in photoreceptor ribbon synapses. Calcineurin specifically binds to the dynamin-1Xb splice isoform of dynamin-1 (Bodmer et al., 2011; Xue et al., 2011), predicting that this dynamin splice variant is present at synaptic ribbons of photoreceptor synapses. Clearly, further possibilities could also apply. In conventional synapses, various mechanisms are known to be installed that regulate endocytosis (for review, see Südhof, 2004, 2012; Shupliakov, 2009; Koch and Holt, 2012; Yamashita, 2012; Yao et al., 2012).

Recently, it was demonstrated that CtBP proteins perform an important role in mediating certain aspects of endocytosis (Bonazzi et al., 2005; Amstutz et al., 2008; Liberali et al., 2008; for review, see Hansen and Nichols, 2009). RIBEYE is also a member of the CtBP protein family and could possibly fulfill a similar role in the ribbon synapse. Recently, the RIBEYE(B) domain was demonstrated to be a lysophosphatidic acidacyltransferase that generates phosphatidic acid (PA) at the synaptic ribbon (Schwarz et al., 2011). PA promotes negative membrane curvature that favors vesicle budding and fission (Jenkins and Frohman, 2005; Roth, 2008; Yang et al., 2008). PA stimulates binding of dynamin to membranes (Burger et al., 2000; Andresen et al., 2002; Roth, 2008) and thus might play a role in distinct aspects of endocytotic membrane traf- 
ficking (Donaldson, 2009; Fine et al., 2011; Lariccia et al., 2011; Malhotra and Campelo, 2011; Campelo and Malhotra, 2012).

Currently, we can only speculate how the endocytic machinery is anchored at the synaptic ribbon complex of photoreceptor synapses. The protein Munc119 is recruited to synaptic ribbons via interaction with RIBEYE (Alpadi et al., 2008). Interestingly, Munc119 was found in a protein complex with dynamin in T lymphocytes and shown to regulate dynamin function (Karim et al., 2010). Therefore, Munc119 might perform a similar role in photoreceptor ribbon synapses by anchoring the endocytic machinery to synaptic ribbons and/or regulating its activity. $\beta$-subunits of voltage-gated $\mathrm{Ca}^{2+}$ channels also bind dynamin (Gonzalez-Gutierrez et al., 2007; Miranda-Laferte et al., 2011; Xue et al., 2011) and thus could be also involved in recruiting the endocytotic machinery. One needs to keep in mind that endocytic retrieval might differ in different types of ribbon synapses. For example, bulk membrane retrieval (Cousin, 2009) is an important mechanism of membrane retrieval in retinal bipolar cells (Holt et al., 2003; Paillart et al., 2003) but is absent in photoreceptor terminals (Rea et al., 2004). Furthermore, multiple modes of endocytosis could coexist in a single synapse (Holt et al., 2003; Paillart et al., 2003; LoGiudice et al., 2009).

\section{References}

Aartsen WM, Arsanto JP, Chauvin JP, Vos RM, Versteeg I, Cardozo BN, Bivic AL, Wijnholds J (2009) PSD95beta regulates plasma membrane $\mathrm{Ca}^{2+}$. pump localization at the photoreceptor synapse. Mol Cell Neurosci 41: 156-165. CrossRef Medline

Alpadi K, Magupalli VG, Käppel S, Köblitz L, Schwarz K, Seigel GM, Sung CH, Schmitz F (2008) RIBEYE recruits Munc119, the mammalian ortholog of the Caenorhabditis elegans protein unc119, to synaptic ribbons of photoreceptor synapses. J Biol Chem 283:26461-26467. CrossRef Medline

Amstutz B, Gastaldelli M, Kälin S, Imelli N, Boucke K, Wandeler E, Mercer J, Hemmi S, Greber UF (2008) Subversion of CtBP1-controlled macropinocytosis by human adenovirus serotype3. EMBO J 27:956-969. CrossRef Medline

Andresen BT, Rizzo MA, Shome K, Romero G (2002) The role of phosphatidic acid in the regulation of the Ras/MEK/Erk signalling cascade. FEBS Lett 531:65-68. CrossRef Medline

Babai N, Bartoletti TM, Thoreson WB (2010) Calcium regulates vesicle replenishment at the cone ribbon synapse. J Neurosci 30:15866-15877. CrossRef Medline

Bai J, Hu Z, Dittman JS, Pym EC, Kaplan JM (2010) Endophilin functions as a membrane-binding molecule and is delivered to endocytic zones by exocytosis. Cell 143:430-441. CrossRef Medline

Bennett V (1983) Proteins involved in membrane-cytoskeleton association in human erythrocytes: spectrin, ankyrin and band 3. Methods Enzymol 96:313-324. CrossRef Medline

Beutner D, Voets T, Neher E, Moser T (2001) Calcium dependence of exocytosis and endocytosis at the cochlear inner hair cell afferent synapse. Neuron 29:681-690. CrossRef Medline

Bodmer D, Ascaño M, Kuruvilla R (2011) Isoform specific dephosphorylation of dynamin 1 by calcineurin couples neurotrophin receptor endocytosis to axonal growth. Neuron 70:1085-1099. CrossRef Medline

Bonazzi M, Spanò S, Turacchio G, Cericola C, Valente C, Colanzi A, Kweon HS, Hsu VW, Polishchuck EV, Polishchuck RS, Sallese M, Pulvirenti T, Corda D, Luini A (2005) CtPB3/BARS drives membrane fission in dynamin-independent transport pathways. Nat Cell Biol 7:570-580. CrossRef Medline

Brodsky FM (1985) Clathrin structure characterized with monoclonal antibodies. I. Analysis of multiple antigenic sites. J Cell Biol 101:2047-2054. CrossRef Medline

Brodsky FM (2012) Diversity of clathrin function: new tricks for an old protein. Annu Rev Cell Dev Biol 28:309-336. CrossRef Medline

Buckley K, Kelly RB (1985) Identification of a transmembrane glycoprotein specific for secretory vesicles of neuronal and endocrine cells. J Cell Biol 100:1284-1294. CrossRef Medline
Burger KN, Demel RA, Schmid SL, de Kruijff B (2000) Dynamin is membrane-active: lipid insertion is induced by phosphoinositides and phosphatidic acid. Biochemistry 39:12485-12493. CrossRef Medline

Campelo F, Malhotra V (2012) Membrane fission: the biogenesis of transport vesicles. Annu Rev Biochem 81:407-427. CrossRef Medline

Clayton EL, Cousin MA (2009) The molecular physiology of activitydependent bulk endocytosis of synaptic vesicles. J Neurochem 111:901914. CrossRef Medline

Cooper NG, McLaughlin BJ (1983) Tracer uptake by photoreceptor synaptic terminals. J Ultrastruct Res 84:252-267. CrossRef Medline

Cousin MA (2009) Activity-dependent bulk synaptic vesicle endocytosis-a fast, high capacity membrane retrieval mechanism. Mol Neurobiol 39: 185-189. CrossRef Medline

Cousin MA, Robinson PJ (2001) The dephosphins: dephosphorylation by calcineurin triggers synaptic vesicle endocytosis. Trends Neurosci 24: 659-665. CrossRef Medline

Di Paolo G, Sankaranarayanan S, Wenk MR, Daniell L, Perucco E, Caldarone BJ, Flavell R, Picciotto MR, Ryan TA, Cremona O, De Camilli P (2002) Decreased synaptic vesicle recycling afficiency and cognitive defects in amphiphysin 1 knockout mice. Neuron 33:789-804. CrossRef Medline

Dittman J, Ryan TA (2009) Molecular circuitry of endocytosis at nerve terminals. Annu Rev Cell Dev Biol 25:133-160. CrossRef Medline

Doherty GJ, McMahon HT (2009) Mechanisms of endocytosis. Annu Rev Biochem 78:857-902. CrossRef Medline

Donaldson JG (2009) Phospholipase D in endocytosis and endosomal recycling pathways. Biochim Biophys Acta 1791:845-849. CrossRef Medline

Donaldson JG, Porat-Shliom N, Cohen LA (2009) Clathrin-independent endocytosis: a unique platform for cell signalling and PM remodelling. Cell Signal 21:1-6. CrossRef Medline

Drenckhahn D, Franz H (1986) Identification of actin-, a-actinin-, and viculin-containing plaques at the lateral membrane of epithelial cells. J Cell Biol 102:1843-1852. CrossRef Medline

Euler T, Hausselt SE, Margolis DJ, Breuninger T, Castell X, Detwiler PB, Denk W (2009) Eyecup scope-optical recordings of light stimulus-evoked fluorescence signals in the retina. Pflugers Arch 457:1393-1414. CrossRef Medline

Ferguson SM, De Camilli P (2012) Dynamin, a membrane remodelling GTPase. Nat Rev Mol Cell Biol 13:75-88. CrossRef Medline

Ferguson SM, Brasnjo G, Hayashi M, Wölfel M, Collesi C, Giovedi S, Raimondi A, Gong LW, Ariel P, Paradise S, O'toole E, Flavell R, Cremona O, Miesenböck G, Ryan TA, De Camilli P (2007) A selective activitydependent requirement for dynamin 1 in synaptic vesicle endocytosis. Science 316:570-574. CrossRef Medline

Fine M, Llaguno MC, Lariccia V, Lin MJ, Yaradanakul A, Hilgemann DW (2011) Massive endocytosis driven by lipidic forces originating in the outer plasmalemmal monolayer: a new approach to membrane recycling and lipid domains. J Gen Physiol 137:137-154. CrossRef Medline

Frank T, Rutherford MA, Strenzke N, Neef A, Pangršič T, Khimich D, Fetjova A, Gundelfinger ED, Liberman MC, Harke B, Bryan KE, Lee A, Egner A, Riedel D, Moser T (2010) Bassooon and the synaptic ribbon organize $\mathrm{Ca} 2+$-channels and vesicles to add release sites and promote refilling. Neuron 68:724-738. CrossRef Medline

Gonzalez-Gutierrez G, Miranda-Laferte E, Neely A, Hidalgo P (2007) The src homology 3 domain of the $\beta$-subunit of voltage-gated calcium channels prmotes endocytosis via dynamin interactions. J Biol Chem 282: 2156-2162. CrossRef Medline

Gray EG, Pease HL (1971) On understanding the organization of the retinal receptor synapses. Brain Res 35:1-15. CrossRef Medline

Griesinger CB, Richards CD, Ashmore JF (2005) Fast vesicle replenishment allows indefatigable signalling at the first auditory synapse. Nature 435: 212-215. CrossRef Medline

Gustafsson MG, Shao L, Carlton PM, Wang CJ, Golubovskaya IN, Cande WZ, Agard DA, Sedat JW (2008) Three-dimensional resolution doubling in wide-field fluorescence microscopy by structured illumination. Biophys J 94:4957-4970. CrossRef Medline

Hansen CG, Nichols BJ (2009) Molecular mechanisms of clathrinindependent endocytosis. J Cell Sci 122:1713-1721. CrossRef Medline

Haucke V, Neher E, Sigrist SJ (2011) Protein scaffolds in the coupling of synaptic exocytosis and endocytosis. Nat Rev Neurosci 12:127-138. CrossRef Medline

Heidelberger R, Thoreson WB, Witkovsky P (2005) Synaptic transmission 
at retinal ribbon synapses. Prog Retin Eye Res 24:682-720. CrossRef Medline

Heymann JA, Hinshaw JE (2009) Dynamins at a glance. J Cell Sci 122:34273431. CrossRef Medline

Hinshaw JE, Schmid SL (1995) Dynamin self-assembles into rings suggesting a mechanism for coated vesicle budding. Nature 374:190-192. CrossRef Medline

Holt M, Cooke A, Wu MM, Lagnado L (2003) Bulk membrane retrieval in the synaptic terminal of retinal bipolar cells. J Neurosci 23:1329-1339. Medline

Hosoi N, Holt M, Sakaba T (2009) Calcium dependence of exo- and endocytic coupling at a glutamatergic synapse. Neuron 63:216-229. CrossRef Medline

Hua Y, Sinha R, Thiel CS, Schmidt R, Hüve J, Martens H, Hell SW, Egner A, Klingauf J (2011) A readily retrievable pool of synaptic vesicles. Nat Neurosci 14:833-839. CrossRef Medline

Irie M, Hata Y, Takeuchi M, Ichtchenko K, Toyoda A, Hirao K, Takai Y, Rosahl TW, Südhof TC (1997) Binding of neuroligins to PSD-95. Science 277:1511-1515. CrossRef Medline

Jackman SL, Choi SY, Thoreson WB, Rabl K, Bartoletti TM, Kramer RH (2009) Role of the synaptic ribbon in transmitting the cone light response. Nat Neurosci 12:303-310. CrossRef Medline

Jenkins GM, Frohman MA (2005) Phospholipase D: a lipid centric review. Cell Mol Life Sci 62:2305-2316. CrossRef Medline

Jockusch WJ, Praefcke GJ, McMahon HT, Lagnado L (2005) Clathrindependent and clathrin-independent retrieval of synaptic vesicles in retinal bipolar cells. Neuron 46:869-878. CrossRef Medline

Karim Z, Vepachedu R, Gorska M, Alam R (2010) UNC119 inhibits dynamin and dynamin-dependent endocytic processes. Cell Signal 22:128137. CrossRef Medline

Keifer J, Vyas D, Houk JC (1992) Sulforhodamine labelling of neural circuits engaged in motor pattern generation in the in vitro turtle brainstemcerebellum. J Neurosci 12:3187-3199. Medline

Kirchhausen T, Macia E, Pelish HE (2008) Use of dynasore, the small molecule inhibitor of dynamin, in the regulation of endocytosis. Methods Enzymol 488:77-93. CrossRef Medline

Koch D, Spiwoks-Becker I, Sabanov V, Sinning A, Dugladze T, Stellmacher A, Ahuja R, Grimm J, Schüler S, Müller A, Angenstein F, Ahmed T, Diesler A, Moser M, Tom Dieck S, Spessert R, Boeckers TM, Fässler R, Hübner CA, Balschun D, Gloveli T, Kessels MM, Qualmann B (2011) Proper synaptic vesicle formation and neuronal network activity critically rely on syndapin I. EMBO J 30:4955-4969. CrossRef Medline

Koch M, Holt M (2012) Coupling exo- and endocytosis: an essential role for PIP2 at the synapse. Biochim Biophys Acta 1821:1114-1132. CrossRef Medline

Koulen P, Fletcher EL, Craven SE, Bredt DS, Wässle H (1998) Immunocytochemical localization of the postsynaptic density protein PSD-95 in the mammalian retina. J Neurosci 18:10136-10149. Medline

Lariccia V, Fine M, Magi S, Lin MJ, Yaradanakul A, Llaguno MC, Hilgemann DW (2011) Massive calcium-activated endocytosis without involvement of classical endocytic proteins. J Gen Physiol 137:111-132. CrossRef Medline

Liberali P, Kakkonen E, Turacchio G, Valente C, Spaar A, Perinetti G, Böckmann RA, Corda D, Colanzi A, Marjomaki V, Luini A (2008) The closure of Pak1-dependent macropinosomes requires the phosphorylation of CtBP1/BARS. EMBO J 27:970-981. CrossRef Medline

Lichtman JW, Wilkinson RS, Rich MM (1985) Multiple innervation of tonic endplates revealed by activity-dependent uptake of fluorescent probes. Nature 314:357-359. CrossRef Medline

Llobet A, Gallop JL, Burden JJ, Camdere G, Chandra P, Vallis Y, Hopkins CR, Lagnado L, McMahon HT (2011) Endophilin drives the fast mode of vesicle retrieval in a ribbon synapse. J Neurosci 31:8512-8519. CrossRef Medline

LoGiudice L, Matthews G (2007) Endocytosis at ribbon synapses. Traffic 8:1123-1128. CrossRef Medline

LoGiudice L, Sterling P, Matthews G (2009) Vesicle recycling at ribbon synapses in the finely branched axon terminals of mouse retinal bipolar neurons. Neuroscience 164:1546-1556. CrossRef Medline

Macia E, Ehrlich M, Massol R, Boucrot E, Brunner C, Kirchhausen T (2006) Dynasore, a cell-permeable inhibitor of dynamin. Dev Cell 10:839-850. CrossRef Medline

Malhotra V, Campelo F (2011) PKD regulates membrane fission to generate
TGN to cell surface transport carriers. Cold Spring Harb Perspect Biol 3:a005280. CrossRef Medline

Mayor HD, Hampton JC, Rosario B (1961) A simple method for removing the resin from epoxy-embedded tissue. J Biophys Biochem Cytol 9:909910. CrossRef Medline

Mercer AJ, Thoreson WB (2011) The dynamic architecture of photoreceptor ribbon synapses: cytoskeletal, extracellular matrix, and intramembrane proteins. Vis Neurosci 28:453-471. CrossRef Medline

Midorikawa M, Tsukamoto Y, Berglund K, Ishii M, Tachibana M (2007) Different roles of ribbon-associated and ribbon-free active zones in retinal bipolar cells. Nat Neurosci 10:1268-1276. CrossRef Medline

Milosevic I, Giovedi S, Lou X, Raimondi A, Collesi C, Shen H, Paradise S, O’Toole E, Ferguson S, Cremona O, De Camilli P (2011) Recruitment of endophilin to clathrin-coated pit necks is required for efficient vesicle uncoating after fission. Neuron 72:587-601. CrossRef Medline

Miranda-Laferte E, Gonzalez-Gutierrez G, Schmidt S, Zeug A, Ponimaskin EG, Neely A, Hidalgo P (2011) Homodimerization of the src homology 3 domain of the calcium channel $\beta$-subunit drives dynamin-dependent endocytosis. J Biol Chem 286:22203-22210. CrossRef Medline

Mizuno N, Jao CC, Langen R, Steven AC (2010) Multiple modes of endophilin-mediated conversion of lipid vesicles into coated tubes: implications for synaptic vesicle endocytosis. J Biol Chem 285:23351-23358. CrossRef Medline

Moser T, Beutner D (2000) Kinetics of exocytosis and endocytosis at the cochlear inner hair cell afferent synapse of the mouse. Proc Natl Acad Sci U S A 97:883-888. CrossRef Medline

Moser T, Brandt A, Lysakowski A (2006) Hair cell ribbon synapses. Cell Tissue Res 326:347-359. CrossRef Medline

Murthy VN, De Camilli P (2003) Cell biology of the presynaptic terminal. Annu Rev Neurosci 26:701-728. CrossRef Medline

Neves G, Lagnado L (1999) The kinetics of exocytosis and endocytosis in the synaptic terminal of goldfish retinal bipolar cells. J Physiol 515:181-202. CrossRef Medline

Neves G, Gomis A, Lagnado L (2001) Calcium influx selects the fast mode of endocytosis in the synaptic terminal of retinal bipolar cells. Proc Natl Acad Sci U S A 98:15282-15287. CrossRef Medline

Nimmerjahn A, Kirchhoff F, Kerr JN, Helmchen F (2004) Sulforhodamine 101 as a specific marker of astroglia in the neocortex in vivo. Nat Methods 1:31-37. CrossRef Medline

Paillart C, Li J, Matthews G, Sterling P (2003) Endocytosis and vesicle recycling at a ribbon synapse. J Neurosci 23:4092-4099. Medline

Pechstein A, Shupliakov O, Haucke V (2010) Intersectin 1: a versatile actor in the synaptic vesicle cycle. Biochem Soc Trans 38:181-186. CrossRef Medline

Praefcke GJ, McMahon HT (2004) The dynamin superfamily: universal membrane tubulation and fission molecules? Nat Rev Mol Cell Biol 5:133-147. CrossRef Medline

Punge A, Rizzoli SO, Jahn R, Wildanger JD, Meyer L, Schönle A, Kastrup L, Hell SW (2008) 3D reconstruction of high-resolution STED microscope images. Microsc Res Tech 71:644-650. CrossRef Medline

Raimondi A, Ferguson SM, Lou X, Armbruster M, Paradise S, Giovedi S, Messa M, Kono N, Takasaki J, Cappello V, O’Toole E, Ryan TA, De Camilli P (2011) Overlapping role of dynamin isoforms in synaptic vesicle endocytosis. Neuron 70:1100-1114. CrossRef Medline

Rea R, Li J, Dharia A, Levitan ES, Sterling P, Kramer RH (2004) Streamlined synaptic vesicle cycle in cone photoreceptor terminals. Neuron 41:755766. CrossRef Medline

Rebrik TI, Korenbrot JI (2004) In intact mammalian photoreceptors, $\mathrm{Ca}^{2+}$-dependent modulation of cGMP-gated ion channels is detectable in cones but not in rods. J Gen Physiol 123:63-75. CrossRef Medline

Ripps H, Shakib M, MacDonald ED (1976) Peroxidase uptake by photoreceptor terminals of the skate retina. J Cell Biol 70:86-96. CrossRef Medline

Roth MG (2008) Molecular mechanisms of PLD function in membrane traffic. Traffic 9:1233-1239. CrossRef Medline

Royle SJ, Lagnado L (2010) Clathrin-mediated endocytosis at the synaptic terminal: bridging the gap between physiology and molecules. Traffic 11:1489-1497. CrossRef Medline

Saheki Y, De Camilli P (2012) Synaptic vesicle endocytosis. Cold Spring Harb Perspect Biol 4:a005645. CrossRef Medline

Sandvig K, Pust S, Skotland T, van Deurs B (2011) Clathrin-independent 
endocytosis: mechanisms and function. Curr Opin Cell Biol 23:413-420. CrossRef Medline

Schacher S, Holtzman E, Hood DC (1976) Synaptic activity of frog photoreceptors: a peroxidase uptake study. J Cell Biol 70:178-192. CrossRef Medline

Schaeffer SF, Raviola E (1978) Membrane recycling in the cone cell endings of the turtle retina. J Cell Biol 79:802-825. CrossRef Medline

Schermelleh L, Carlton PM, Haase S, Shao L, Winoto L, Kner P, Burke B, Cardoso MC, Agard DA, Gustafsson MG, Leonhardt H, Sedat JW (2008) Subdiffraction multicolor imaging of the nuclear periphery with 3D structured illumination microscopy. Science 320:1332-1336. CrossRef Medline

Schermelleh L, Heintzmann R, Leonhardt H (2010) A guide to superresolution fluorescence microscopy. J Cell Biol 190:165-175. CrossRef Medline

Schmid SL, Frolov VA (2011) Dynamin: fundamental design of a membrane fission catalyst. Annu Rev Cell Dev Biol 27:79-105. CrossRef Medline

Schmitz F (2009) The making of synaptic ribbons: how they are built and what they do. Neuroscientist 15:611-624. CrossRef Medline

Schmitz F, Königstorfer A, Südhof TC (2000) RIBEYE, a protein's journey through evolution provides insights into synaptic ribbon function. Neuron 28:857-872. CrossRef Medline

Schmitz F, Natarajan S, Venkatesan JK, Wahl S, Schwarz K, Grabner CP (2012) EF hand-mediated Ca- and cGMP-signaling in photoreceptor synaptic terminals. Front Mol Neurosci 5:26. CrossRef Medline

Schnee ME, Santos-Sacchi J, Castellano-Muñoz M, Kong JH, Ricci AJ (2011) Calcium-dependent synaptic vesicle trafficking underlies indefatigable release of the hair cell afferent fiber synapse. Neuron 70:326-338. CrossRef Medline

Schoch S, Gundelfinger ED (2006) Molelcular organization of the presynaptic active zone. Cell Tissue Res 326:379-391. CrossRef Medline

Schoch S, Mittelstaedt T, Kaeser PS, Padgett D, Feldmann N, Chevaleyre V, Castillo PE, Hammer RE, Han W, Schmitz F, Lin W, Südhof TC (2006) Redundant functions of RIM1alpha and RIM2alpha in $\mathrm{Ca}^{2+}$-triggered neurotransmitter release. EMBO J 25:5852-5863. CrossRef Medline

Schwarz K, Natarajan S, Kassas N, Vitale N, Schmitz F (2011) The synaptic ribbon is a site of phosphatidic acid generation in ribbon synapses. J Neurosci 31:15996-16011. CrossRef Medline

Scita G, Di Fiore PP (2010) The endocytic matrix. Nature 463:464-473. CrossRef Medline

Shupliakov O (2009) The synaptic vesicle cluster: a source of endocytic proteins during neurotransmitter release. Neuroscience 158:204-210. CrossRef Medline

Smith SM, Renden R, von Gersdorff H (2008) Synaptic vesicle endocytosis: fast and slow modes of membrane retrieval. Trends Neurosci 31:559-568. CrossRef Medline

Snellman J, Mehta B, Babai N, Bartoletti TM, Akmentin W, Francis A, Matthews G, Thoreson W, Zenisek D (2011) Acute destruction of the synaptic ribbon reveals a role for the ribbon in vesicle priming. Nat Neurosci 14:1135-1141. CrossRef Medline

Spassova MA, Avissar M, Furman AC, Crumling MA, Saunders JC, Parsons TD (2004) Evidence that rapid replenishment of the synaptic ribbon mediates recovery from short-term adaptation at the hair cell afferent synapse. J Assoc Res Otolaryngol 5:376-390. CrossRef Medline

Südhof TC (2004) The synaptic vesicle cycle. Annu Rev Neurosci 27:509547. CrossRef Medline

Südhof TC (2012) Calcium control of neurotransmitter release. Cold Spring Harb Perspect Biol 4:a011353. CrossRef Medline

Takahashi N, Kishimoto T, Nemoto T, Kadowaki T, Kasai H (2002) Fusion pore dynamics and insulin granule exocytosis in the pancreatic islet. Science 297:1349-1352. CrossRef Medline

Takei K, McPherson PS, Schmid SL, De Camilli P (1995) Tubular membrane invaginations coated by dynamin rings are induced by GTP- $\gamma-\mathrm{S}$ in nerve terminals. Nature 374:186-190. CrossRef Medline

Teng H, Cole JC, Roberts RL, Wilkinson RS (1999) Endocytic active zones: hot spots for endocytosis in vertebrate neuromuscular terminals. J Neurosci 19:4855-4866. Medline
Tian M, Xu CS, Montpetit R, Kramer RH (2012) Rab3A mediates vesicle delivery at photoreceptor ribbon synapses. J Neurosci 32:6931-6936. CrossRef Medline

tom Dieck S, Brandstätter JH (2006) Ribbon synapses of the retina. Cell Tissue Res 326:339-346. CrossRef Medline

tom Dieck S, Altrock WD, Kessels MM, Qualmann B, Regus H, Brauner D, Fejtová A, Bracko O, Gundelfinger ED, Brandstätter JH (2005) Molecular dissection of the photoreceptor ribbon synapse: physical interaction of Bassoon and RIBEYE is essential for the assembly of the ribbon complex. J Cell Biol 168:825-836. CrossRef Medline

Townes-Anderson E, MacLeish PR, Raviola E (1985) Solitary rod photoreceptors from mature salamander retina: ultrastructure and uptake ofhorseradish peroxidase. J Cell Biol 100:175-188. CrossRef Medline

Townes-Anderson E, Dacheux RF, Raviola E (1988) Rod photoreceptors dissociated from the adult rabbit retina. J Neurosci 8:320-331. Medline

Van Hook MJ, Thoreson WB (2012) Rapid synaptic vesicle endocytosis in cone photoreceptors of salamander retina. J Neurosci 32:18112-18123. CrossRef Medline

Wakeham DE, Abi-Rached L, Towler MC, Wilbur JD, Parham P, Brodsky FM (2005) Clathrin heavy and light chain isoforms originated by independent mechanisms of gene duplication during chordate evolution. Proc Natl Acad Sci U S A 102:7209-7214. CrossRef Medline

Warnock DE, Terlecky LJ, Schmid SL (1995) Dynamin GTPase is stimulated by crosslinking through the c-terminal proline-rich domain. EMBO J 14:1322-1328. Medline

Wilbur JD, Hwang PK, Brodsky FM (2005) New faces of the familiar clathrin lattice. Traffic 6:346-350. CrossRef Medline

Wojcik SM, Rhee JS, Herzog E, Sigler A, Jahn R, Takamori S, Brose N, Rosenmund C (2004) An essential role for vesicular glutamate transporter 1 (VGLUT1) in postnatal development and control of quantal size. Proc Natl Acad Sci U S A 101:7158-7163. CrossRef Medline

Wu LG, Ryan TA, Lagnado L (2007) Modes of vesicle retrieval at ribbon synapses, calyx-type synapses and small central synapses. J Neurosci 27: 11793-11802. CrossRef Medline

Wu W, Xu J, Wu XS, Wu LG (2005) Activity-dependent acceleration of endocytosis at a central synapse. J Neurosci 25:11676-11683. CrossRef Medline

Wu XS, McNeil BD, Xu J, Fan J, Xue L, Melicoff E, Adachi R, Bai L, Wu LG (2009a) $\mathrm{Ca}^{2+}$ and calmodulin initiate all forms of endocytosis during depolarization of a nerve terminal. Nat Neurosci 12:1003-1010. CrossRef Medline

Wu Y, Matsui H, Tomizawa K (2009b) Amphiphysin I and regulation of synaptic vesicle endocytosis. Acta Med Okayama 63:305-323. Medline

Xue J, Graham ME, Novelle AE, Sue N, Gray N, McNiven MA, Smillie KJ, Cousin MA, Robinson PJ (2011) Calcineurin selectively docks with the dynamin $1 x b$ splice variant to regulate activity-dependent bulk endocytosis. J Biol Chem 286:30295-30303. CrossRef Medline

Yamashita $\mathrm{T}$ (2012) $\mathrm{Ca}^{2+}$-dependent regulation of synaptic vesicle endocytosis. Neurosci Res 73:1-7. CrossRef Medline

Yang JS, Gad H, Lee SY, Mironov A, Zhang L, Beznoussenko GV, Valente C, Turacchio G, Bonsra AN, Du G, Baldanzi G, Graziani A, Bourgoin S, Frohman MA, Luini A, Hsu VW (2008) A role for phosphatidic acid in COPI vesicle fission yields insights into Golgi maintenance. Nat Cell Biol 10:1146-1153. CrossRef Medline

Yao LH, Rao Y, Varga K, Wang C-Y, Xiao P, Lindau M, Gong LW (2012) Synaptotagmin-1 is necessary for the $\mathrm{Ca}^{2+}$ dependence of clathrinmediated endocytosis. J Neurosci 32:3778-3785. CrossRef Medline

Yoshida Y, Kinuta M, Abe T, Liang S, Araki K, Cremona O, Di Paolo G, Moriyama Y, Yasuda T, De Camilli P, Takei K (2004) The stimulatory action of amphiphysin on dynamin function is dependent on lipid bilayer curvature. EMBO J 23:3483-3491. CrossRef Medline

Zenisek D (2008) Vesicle association and exocytosis at ribbon and extraribbon sites in retinal bipolar cell presynaptic terminals. Proc Natl Acad Sci U S A 105:4922-4927. CrossRef Medline

Zenisek D, Steyer JA, Almers W (2000) Transport, capture and exocytosis of single synaptic vesicles at active zones. Nature 406:849-854. CrossRef Medline 